\title{
Environmental sustainability of typical agro-food products: a scientifically sound and user friendly approach
}

\author{
Hamid El Bilali ${ }^{\star}$, Generosa Calabrese* ${ }^{\star}$ Massimo Iannetta**, \\ Milena Stefanova**, Flavio Paoletti ${ }^{\star * \star}$, Gaetano Ladisa*, \\ Francesco Bottalico*, Roberto Capone*
}

DOI: $10.30682 / \mathrm{nm} 2002 \mathrm{e}$

JEL codes: O13, Q01, Q18

\begin{abstract}
The paper introduces an approach, developed in Agriculture \& Quality programme, to evaluate the environmental sustainability of Apulian quality agro-food products that is integrated in the regional quality scheme "Quality Products". It highlights the methodological approach adopted, the sustainability themes identified and the indicators selected. Indicators measurable at the farm/firm level were selected in relation to the following environmental themes: biodiversity, land use and management, energy use and climate change, use of chemical inputs, and responsible management of by-products and waste. A scoring scale was developed for each indicator; going from 0 (unsustainable) to 10 (very sustainable) with 5 corresponding to the sustainability threshold or reference value. The presented approach is both robust and user friendly and is in line with the principle entailing continuous improvement; the key sustainability thresholds will be periodically reviewed and updated. It represents a practical and innovative way to develop an information scheme for typical agri-food products and can be, with some refinement and contextualisation, easily scaled up to other territories.
\end{abstract}

Keywords: Environmental sustainability, Biodiversity, Quality agro-food products, Sustainability themes, Indicators.

\section{Introduction}

Agriculture is facing an unprecedented confluence of environmental pressures and challenges such as land degradation, climate change, water scarcity and pollution, biodiversity loss (FAO, 2014a); and there are several interconnected and mutually reinforcing trends in food production and consumption (e.g. unhealthy and unsustain- able diets, unbalanced supply chains), which pose serious challenges on the overall sustainability of food systems (Friedmann and Mcnair, 2008). Sustainable agri-food systems are needed to provide economic benefits for rural dwellers, to ensure socially appropriate solutions to the food and nutrition security challenges and also to limit the negative environmental effects of agriculture (FAO, 2014a; 2014b).

\footnotetext{
* International Centre for Advanced Mediterranean Agronomic Studies (CIHEAM-Bari), Valenzano (Bari), Italy.

** National Agency for New Technologies, Energy and Sustainable Economic Development (ENEA), Rome, Italy.

*** Council for Agricultural Research and Economics (CREA), Rome, Italy.

Corresponding author: elbilali@iamb.it
} 
In the complex socio-economic and environmental landscape in which food systems operate today, traditional local products present an interesting option for rural development to reverse negative environmental and socio-economic trends. A central issue is thus how to emerge local resources, which are little known or ill-utilised (Fonte, 2006). Many scholars recognise that it is critical that typical products reach the consumer embedded with information on their quality attributes, including indication of environmental performance and quality (Brunori et al., 2016; Marsden, 2013; van der Ploeg et al., 2009).

The environmental quality of typical products is strictly linked to the territorial context into which production and consumption activities are embedded - its natural geomorphologic, chemical, biological resources constitute an important part of the product 'typicality', while continuous reproduction and care for such resources is an important characteristic of the environmental quality of typical food production systems (van der Ploeg et al., 2009).

One way to embed information about environmental quality and performance of food products is through environmental labels and information schemes (ELIS). The rationale behind such schemes is the belief that they can drive gradual market transformation by promoting food products whose production process respect the environment (UNEP, 2015; UNFSS, 2016). The environmental effectiveness of an ELIS is a function of (1) the stringency and quality of the standard being used, (2) its appropriateness for the production and supply chain, and (3) the level of its market uptake (Prag et al., 2016). The stringency and quality of schemes depend on various characteristics (Gruère, 2013), including the methods of environmental assessment adopted.

Since the assessment of the environmental, economic and social sustainability of agriculture and agriculture products is crucial for transition towards sustainable agro-food systems (Chaudhary et al., 2018; El Bilali, 2019; Poppe et al., 2016), there are different holistic and non-holistic approaches and frameworks for the assessment of sustainability (FAO, 2013; Latruffe et al., 2016; Talukder, 2016). Reytar et al. (2014) analysed the landscape of indicators and indices used in the assessment of environmental sustainability in agriculture and found that the most common agri-environmental themes are climate change (GHG emissions), water use, agriculture policies (e.g. agriculture subsidies). In their overview, Latruffe et al. (2016) confirm that a multitude of themes are covered in the assessment of environmental sustainability (e.g. climate change and GHG emissions; biodiversity; land/soil management; use of nutrients, pesticides and resources e.g. energy and water) and, consequently, a high indicators number. These findings confirm the complexity of environmental sustainability assessment in the agro-food arena.

A multitude of tools and models has been used to assess the environmental sustainability in the agro-food sector. These include methods based on Life Cycle Analysis (LCA) and Life Cycle Thinking (Brentrup et al., 2004), such as Carbon footprint (Dubey and Lal, 2009), Water footprint (Mekonnen and Hoekstra, 2012), Ecological footprint analysis (Naderi Mahdei et al., 2015), or other methods such as Environmental risk mapping (Delbaere and Nieto Serradilla, 2004), SALSA - Simulation Tool to Assess Ecological Sustainability of Agricultural Production (Eriksson et al., 2005). However, their scientific soundness and user-friendliness are still critical issues (Talukder, 2016).

A further weakness of these tools for the assessment of environmental sustainability is that they are not easily integrated and usable in certification schemes. To fill this gap, the present paper introduces a robust, yet user friendly method, for the assessment of environmental sustainability of agro-food products in Apulia region (south-eastern Italy) that is integrated in the regional quality scheme and is suitable to communicate to stakeholders, primarily consumers and policy makers, the environmental performance and quality of these products. 


\section{Material and Methods}

\subsection{Agriculture and Quality project of Apulia region: combining typicality, quality and sustainability}

Apulia is a peninsular region located in the south-east of Italy. It has a land area of 1,954,090 hectares $(6.5 \%$ of the Italian territory) and a resident population of $4,050,072$ inhabitants $(6.7 \%$ of the Italian population); its rural areas amount to $97.1 \%$ of the regional area, within which resides $85.1 \%$ of the total population. A strong diversity of production characterizes the Apulian agriculture and its 272,000 farms (Apulia Region Authority, 2013). The Apulian economy is strongly linked to its typical agri-food products and the region gives important value to the traditions related to food and to the typicality of the products (Apulia Region, 2010; MiPAAF, 2013). According to the $19^{\text {th }}$ edition of the list of Italian traditional food products (MiPAAFT, 2019), there are 285 traditional agro-food products in Apulia region: 13 alcoholic beverages, 24 meat products, 1 condiment, 17 cheeses, 1 fat, 107 plant products, 64 fresh pasta and cereal products, 45 gastronomy products, 9 fish preparations, and 4 animal products.

In the framework of Agriculture \& Quality programme (A\&Q) (2013-2015), Regione Puglia (Regional Government of Apulia) aimed to valorise and qualify regional typical and traditional food products through the creation of the quality scheme "Prodotti di Qualità" (Quality products, $\mathrm{PdQ}$ ) aiming to ensure both origin and quality of food products by complying with the product technical specification approved by Regione Puglia. In this framework, the International Centre for Advanced Mediterranean Agronomic Studies (CIHEAM-Bari) - in collaboration with different Italian institutions namely the National Agency for New Technologies, Energy and Sustainable Economic Development (ENEA), the Council for Agricultural Research and Economics (CREA), the National Research Council (CNR), the Forum on Mediterranean Food Cultures, the University of Bologna and the University of Naples Federico II - carried out a pilot project to assess and promote the sustainability of the products belonging to the quality scheme (Capone et al., 2016). The aim is to ensure that the products adhering to the regional quality scheme satisfy not only the quality requirements, but also sustainability ones thanks to the development of a methodological approach and guidelines to assess the sustainability of Apulian quality typical products. The approach for the assessment of diets sustainability considers four pillars: environment, economy, society-culture and nutrition-health (Dernini et al., 2013; Lacirignola et al., 2012). According to this methodological approach, an agro-food product can be considered sustainable only if it is so for each pillar of sustainability: environmental, economic (Capone et al., 2016), socio-cultural (Moscatelli et al., 2017) and nutrition-health (Azzini et al., 2018).

The working group on environmental sustainability - including experts from ENEA, CREA and CIHEAM-Bari - identified and refined the selection of sustainability themes and indicators in accordance with the specificities of the region's typical products, the conceptual framework adopted as well as the requirements of the A\&Q project that had in view the activation of a specific certification scheme to promote the transition of the Apulia food system toward a more sustainable one.

\subsection{Methodological approach for the selection of environmental themes and indicators}

The starting point of the adopted approach is a strategic, normative definition of sustainable food value chain (VC), as developed in FAO (2014c), which allows to tackle the question of food system transformation. This type of approach is conceptually different from descriptive/structural approaches in VC analysis, such as those deriving from commodity chain analysis and LCA-based indicators (Garnett, 2014; Stefanova \& Iannetta, 2016). It is not simply a matter of how to do things better, but how to change toward production/consumption systems, which are able to deliver environmental and societal benefits. A further criterion for the 
selection of environmental indicators was their ability to inform the relation between the choice of the operators (cf. economic activities) and the ecological component of the territorial context.

The adopted methodological approach follows the guidelines for Sustainability Assessment of Food and Agricultural Systems (SAFA) of FAO (FAO, 2013) for the steps of definition of system boundaries, contextualisation and indicators selection:

1. System Boundary: The focus of the work is on products (and supply chains), participating in the scheme for quality typical products from Apulia region. Therefore, the definition of system boundary, spatial and temporal scales are those adopted by the A\&Q project: regional boundary, year-based time boundaries, selecting a baseline year, compatible with the latest official statistical data on agri-food census. For each indicator, a selection of the benchmarks with which typical products are compared was performed.

2. Contextualisation: As suggested by SAFA, in order to select indicators, information should be gathered also about surrounding context of the value chains. In the framework of A\&Q project, there have been detailed analyses focussing on the socio-economic conditions of the regional agri-food sector, positioning it in national and international perspectives, as well as environmental conditions and surveys were performed in order to understand which thematic areas are of particular importance for consumers (Capone et al., 2017). This contextual information was used in order to select the environmental themes and sub-themes, the measurement units of indicators, as well as the sources of data and data collection methods.

3. Indicators can be integrated into indices in order to make easier comparisons, this implies weighting (e.g. equal weighting, differential weighting) and aggregating (e.g. arithmetic average, geometric average, setting a 'knock-out' threshold) the constituent indicators (Reytar et al., 2014). For each indicator, a selection of the benchmark was performed with which typical products are compared, considering key sustainability thresholds to be reviewed (and up- dated) based on data periodically published by the national statistical authority (Istituto Nazionale di Statistica - ISTAT). The present environmental sustainability assessment approach considers the following indices: agriculture biodiversity management index; land management index; total energy use index; total chemical input consumption index; responsible management of production by-products and waste. It uses equal weighting (for indicators within indices/themes as well as among indices) and arithmetic average for aggregating both indicators and indices. A scoring system was developed for each indicator; from 0 (unsustainable) to 10 (very sustainable) with 5 corresponding to sustainability threshold or reference value. Actually, the scores of the indicators (not their effective values) are aggregated to obtain an overall score on the environmental performance/sustainability of a product.

\section{Results and Discussion}

\subsection{Environmental sustainability: guiding criteria and themes}

Environmental sustainability consists in the capacity to maintain over time the quality and reproducibility of natural resources (water, soil, biodiversity, climate resources, etc.) through their rational use as well as paying due attention to the negative impacts on the environmental resources. Therefore, the actors of the certified quality supply chain must commit to implementing an environmental management system aimed at a better use of resources (soil, biodiversity, energy, etc.) and, at the same time, pollution reduction (cf. reducing the use of production inputs such as fertilizers, pesticides, energy; waste management) through an approach based on the use of sustainable agricultural practices and a reorganization of production environments (firm, plants, etc.). To have products that are sustainable from the environmental point of view, the plant and animal production practices adopted by the companies that adhere to the regional scheme of Quality products (PdQ) must at least respect the guidelines and criteria of the integrated production (Dir. 
2009/128/CE) and preferably be equivalent to those of organic farming (Reg. 848/2018/CE).

In this context, the working group on environmental sustainability has identified some key concepts behind ways of managing production processes that contribute to a greater sustainability of the agro-food system.

Special attention must be paid to certain guiding criteria such as:

- Preserving and increasing agro-biodiversity (e.g. plant varieties, local animal breeds, functional biodiversity, etc.) by adopting an ecosystem approach that takes into account the conservation of the agricultural landscape and support to production processes that derive from natural biodiversity (pollination, pest resistance, agricultural system resilience, etc.).

- Improving the efficiency of the use of resources, especially water resources and energy (both direct energy use as well as indirect energy use i.e. energy embedded in chemical inputs such as fertilizers, pesticides, etc.).

- Adopting sustainable practices that are necessary to reduce all types of degradation and depletion of soil, water and biodiversity (e.g. soil erosion, desertification, soil fertility reduction, water pollution, etc.).

- Reducing environmental pollution by decreasing the amount of chemical inputs used as well as the production of waste and by-products that should be managed responsibly and, where possible, enhanced through recovery, re-use and/ or recycling processes.

- Promoting models of firm and supply chain organization that enable the reduction of losses along the food chain.

In compliance with the above-mentioned guiding criteria, and taking into consideration national and international literature, the following environmental sustainability themes were identified by the working group: biodiversity; land use and management; energy use and climate change; use of chemical inputs (fertilizers, soil conditioners/amendments, pesticides); responsible management of production waste and by-products. For each theme, a set of indicators, that meet the guiding criteria, has been identified.

\subsection{Indexes and indicator sets}

\subsubsection{Agriculture biodiversity}

Biodiversity is a resource or asset to be safeguarded and, as such is also an indicator of sustainability. The agricultural farm is therefore the physical place where the farmer's decisions interact with the specificities of the territory to reach a productive result. Each farmer inherits an environmental capital in terms of natural resources that he/she somehow manages to achieve a production and, therefore, a profit based on social and economic pressures and demands. Each farmer must deal with the specific structure of the territory and with particular structural conditions that, in turn, are determined by the context not only physical but also socio-economic (plots, climate, infrastructure, market, etc.); within these constraints he/she designs the organization and management of the firm. From this interaction between the choices of the farmer and the territories in which he/she operates, derives a wide variety of agricultural and cultural environments, which overall determine the quality of the landscape and the environment (Calabrese et al., 2015; Calabrese et al., 2013). Each rural area is, therefore, the complex result of local variations in climate, soil, economic relations, social structure and adaptive responses. In the agroecosystem hierarchy, the farm is the fundamental organization level and the functional unit of the territory (Caporali et al., 2003).

If one takes into consideration the agricultural firm level, as the farm productive organization is the result of farmer's choices, by analysing the farm structural components that make up the system, it would be able to tackle in a global, holistic, systemic way, all the farmer's decisions concerning all the complex ecological and productive processes that can influence the state of the agro-ecosystem in relation to biodiversity.

As a result, the main areas of investigation in relation to the major biological and ecological processes going on at farm level are:

1. The plot: It is the smallest unit of the agro-ecosystem (agro-ecosystem unit), on which the farmer decides the type of crop, chooses the type of management (pest control 
and management, soil fertility, etc.) and on which determines positive or negative effects on flora and fauna.

2. The farm: The farm is the smallest functional unit to be considered for sustainable management; at the level of which the farmer makes decisions and organizational choices according to the technical-economic context of the territory in which he operates in the context of the general economic policy.

3. Ecological infrastructures (or Ecological Focus Areas).

The Ecological Focus Areas can be present at plot and farm levels. Ecological focus area means any infrastructure on the farm or within 150 meters from it that has an ecological value for the farm (IOBC, 2004). The presence of ecological focus areas ${ }^{1}$ on the farm is very important also for the purposes of the Common Agricultural Policy (Ecological Focus Area and set-aside area). They are used to ensure the presence of associated biodiversity on the farm in order to help support production processes through the provision of environmental and ecosystem services. The ecological focus areas are very diverse e.g. hedges, wildflower strips, strips managed without pesticides use (conservation headlands), grass strips, small ponds, dry stone walls, dirt roads, piles of stones or other materials. In addition to these semi-wild areas, even some of the productive areas may serve as ecological focus areas, such as pastures, meadows and orchards managed extensively and fallows, which contribute to the conservation of biodiversity on the farm.

For the analysis of environmental sustainability with reference to the impact on and the need to preserve agricultural biodiversity, qualitative and quantitative indicators have been proposed (Table 1; see also Supplementary material 1), which assess the sustainability of the choices made by agricultural entrepreneurs in relation to farm agronomic practices and spatial organization of production also in no directly productive areas.

\subsubsection{Land use and management}

Soil is subject to many threats whose main ones are water erosion, organic matter reduction, compaction, salinization, desertification, hydrogeological risk, biodiversity decrease, and punctual and widespread pollution.

Agricultural activity constitutes a factor of land defence from other uses that reduce its environmental value, but can also determine harmful effects, of physical and/or biological nature, on soil quality. The Communication of the European Commission COM(2006)231 on Thematic Strategy for Soil Protection (European Commission, 2006b) and the proposal for a directive establishing a framework for the protection of soil (European Commission, 2006a) set out common principles for protecting soils across the EU. They identify the risk of erosion as one of the main problems of European soils. The Soil Thematic Strategy was adopted in February 2012 and includes four pillars, namely awareness raising, research, integration, and legislation (European Commission, 2012). Moreover, rules for direct support schemes under the Common Agricultural Policy (CAP) contemplate erosion control as one of the main requirements for maintaining agricultural land in good agricultural and environmental conditions.

Water erosion of soils, an extremely complex and inevitable natural phenomenon, depends on the climatic conditions, the geological, ped-

\footnotetext{
1 "Since 2015, every farmer in the European Union who claims a direct payment and has more than 15 hectares of arable land is obliged to have $5 \%$ of his arable land covered by ecological focus areas. These are areas which bring benefits for the environment, improve biodiversity and maintain attractive landscapes (such as landscape features, buffer strips, afforested areas, fallow land, areas with nitrogen-fixing crops, etc.). Some exceptions to this general rule apply, for example to farmers who have more than $75 \%$ of their area under grassland. The obligation to have $5 \%$ of land covered by ecological focus areas may be increased to 7\% subject to a European Commission report in 2017 and a legislative proposal from the Commission. This obligation is one of three 'greening' measures of the Common Agricultural Policy 2014-2020 - the others being the maintenance of permanent grassland and crop diversification." (European Commission, 2015).
} 
ological, hydrological, morphological and vegetation characteristics of the territory; it can be accelerated by human activities, in particular by agro-silvo-pastoral activities (cultivation types, ploughing and cropping systems, forest management, grazing), up to determining the onset of serious economic and environmental problems. The content of organic matter in soils is influenced by the climatic conditions and cultivation techniques.

A phenomenon linked to soil degradation processes and in particular to surface erosion is soil compaction. The compaction of soils involves significant changes in the structural properties, reducing the drainage capacity of the soil and consequently increasing the superficial flow and the risk of erosion; it also causes changes in the hydraulic and thermal conductivity, the balance and characteristics of the liquid and gaseous phases of the soil itself and asphyxia phenomena. Soil compaction is favoured by natural phenomena (rain, swelling of the clays,...) and, above all, factors of anthropogenic origin linked to livestock farming (overgrazing) and cropping practices, such as the traffic of agricultural machinery. The risk of compaction is obviously higher where high loads (in terms of tractors / combine harvesters) are concentrated on treatable UAA of reduced size.

A useful element to evaluate the intensification of agricultural practices with respect to the national context is the consumption of mineral fertilizers. Another risk factor related to the intensification of agricultural practices, and relevant not only for the soil but also for the air and the safety of the agro-food products themselves, is the use of plant protection products. The use of fertilizers and pesticides can also have indirect effects on ecosystems, causing, for example, an impoverishment of soil biodiversity and a consequent degradation of soil structure and properties.

Environmental indicators relating to land use and management theme are reported in Table 1 (see also Supplementary material 2).

\subsubsection{Energy use and climate change}

The activities of agricultural companies cause both GHG emissions and alterations in the se- questration into and release of carbon from the soil. These can have positive or negative effects on the climate (Mackey et al., 2013).

At farm level, direct GHG emissions are due to:

- Use of energy (in combustion processes, in mobile or fixed sources).

- Emissions from the soil (especially $\mathrm{CO}_{2}$ due to the decomposition of organic matter and $\mathrm{N}_{2} \mathrm{O}$ emissions due to nitrification and denitrification processes). These emissions are influenced by the application of mineral and organic fertilizers and by the intensity of cultivation operations as well as by soil and climatic conditions.

- Methane emissions due to enteric fermentation processes in ruminant production systems.

- Manure management and animal housing systems.

Indirect emissions are due to the production, storage and transport of various inputs (fertilizers, pesticides, fuels, feed, lubricants, seeds, plastic material, machinery, etc.) used in agricultural production. Several LCA studies indicate that the contribution due to the production of mineral nitrogen fertilizers is significant in plant production, while there are few studies concerning contribution to climate impacts due to the use of pesticides and lubricants. In the livestock sector, indirect impacts are linked to the production and transport of feed. In fact, the import of feed causes high impacts on the climate not only due to their intensive production and related transport, but above all due to the change in the use of the soil associated with the production of soya, corn and other feed crops in other continents.

The most used indicators currently linked to climate change are aimed at accounting for direct and indirect GHG emissions due to different agricultural activities. Traditionally, these accounts do not include $\mathrm{CO}_{2}$ emissions due to the decomposition of organic matter in soils. Only the most recent policies aim at accounting for changes in carbon stock in the soil.

For the accounting of GHG emissions, the chosen approach is based on the adoption of proxy indicators. Indicators for the dynamics of organic carbon in soils are not be consid- 
ered since there are still few studies that allow to translate the multitude of complex interactions in soil-plant-atmosphere systems, resulting from various agricultural practices, into a simple score system that adequately represents their effects on the climate. For the same reasons, indicators concerning methane emissions due to fermentation in the gastric tracts of ruminants have been excluded from the analysis.

Therefore, in this phase, we consider it useful to consider direct and indirect consumption of combustible energy sources, as indicators for the processes responsible for GHG emissions in agriculture. These indicators are aggregated into a composite index, using the weighted arithmetic mean, which acts as a proxy for the impacts on climate change (Table 1; see also Supplementary material 3).

Direct energy consumption is calculated using final energy consumption indicator i.e. the energy consumed by the farms to meet their production needs. This energy is accounted for on the basis of production for the agri-food sector, but also on the basis of that destined for other sectors (such as feed, textiles, etc.).

Regarding indirect consumption, the following inputs, purchased by the agricultural firm, are considered: mineral fertilizers based on phosphorus and nitrogen, lubricants, pesticides, feed, and plastic materials. It should be noted that indirect consumption for self-produced inputs by the agricultural firm is already counted, as data collection takes place at firm level, and not for each single product. The energy required for the production of capital goods (e.g. agricultural infrastructure and machinery) was not taken into consideration. Potassium-based mineral fertilizers, micronutrient-based mineral products intended for crop nutrition, seeds purchased by the agricultural firm and pharmaceutical products administered to farm animals were also excluded. In addition, energy consumption due to the production of organic fertilizers purchased by the firm was excluded, both because of the lack of data and because their use brings benefits in terms of reintegration of the organic matter content of agricultural land, with consequent benefits in terms of carbon storage.
For individual indicators, some additional notes are included hereafter:

- Final consumption of direct energy: The indicator considers the oil products purchased by the agricultural firm mainly for the operation of agricultural machinery, natural gas for heat production and electricity purchased from the electricity distribution network. This limit is due to the availability of statistical data in Apulia region, which take into consideration only the energy sources listed above, while the biomass sources purchased by the firm from third parties are not taken into account.

- Energy content of fertilizers, pesticides, lubricants and plastic materials: These inputs require energy sources both for the production of energy used, for the corresponding production processes, and as primary materials (feedstock energy). For various reasons related to the lack of updated studies of the sector, it was decided to consider the whole energy embedded in inputs, assuming the existence of a correlation between the energy content itself and the climate impacts related to the agricultural activity of the examined companies.

\subsubsection{Chemical input consumption}

The use of chemical inputs at the level of primary production processes is undoubtedly a useful element in assessing the intensification of agricultural practices with respect to a national and regional context. The chemical inputs (fertilisers, fungicides, insecticides and acaricides, herbicides) in the present set of indicators (Table 1; see also Supplementary material 4) have been taken into consideration both in the case of soil/land management and energy use. However, in relation to this theme a specific reference is made instead to the quantities used to highlight the (un)sustainability of the use of these inputs with respect to the concrete risk of pollution of the agricultural system and, above all, of the environment.

The use of fertilizers, the most common of which are based on nitrogen and phosphorus, and of pesticides (fungicides, insecticides, acaricides and herbicides) can have different impacts depending on environmental contexts, crops, 
formulations and active ingredients used, as well as in relation to any additives or methods of administration and distribution. Another element of uncertainty in the environmental impact assessment, lies in the possibility of some molecules to persist for more or less long periods in the environment, to undergo modification processes and, therefore, to have a different fate and a different impact on natural resources and biodiversity. Currently, there are no exhaustive data on the use of chemical inputs by crop, territory and crop management system, even if many efforts are being made in this direction. On the other hand, it is useful to trace management choices and, if possible, direct them towards sustainability. A firm-level analysis that evaluates the agricultural entrepreneur's choices must necessarily be based on reference values linked to the Apulian territory, but which are not necessarily referring to management choices linked to specific agricultural production systems (integrated, organic and conventional). The idea is not to interfere 'ideologically' with the entrepreneur's choices, but to evaluate them in relation to what happens on the reference (regional) territory. Therefore, it was chosen to refer for the various indicators to the values of the statistical series reported in ISTAT publications; which may also be periodically reviewed in light of the change in the management of production processes traced precisely by ISTAT on a continuous and periodic basis.

\subsubsection{Responsible management of produc- tion by-products and waste}

The Framework Directive 2008/98/EC of the European Parliament and the Council of 19 November 2008 on waste (Waste Directive) defined a so-called "Waste hierarchy" (Figure 1). In fact, to better protect the environment and human health, Member States must take measures for the treatment of their waste in accordance with the following hierarchy, which applies in order of priority: prevention, preparation for re-use, recycling, recovery of other type (e.g. energy recovery), disposal. According to the Waste Directive, every producer or other waste holder must personally take care of it or deliver it to an entity or a firm.
Figure 1 - Waste management hierarchy according to the EU Waste Directive.

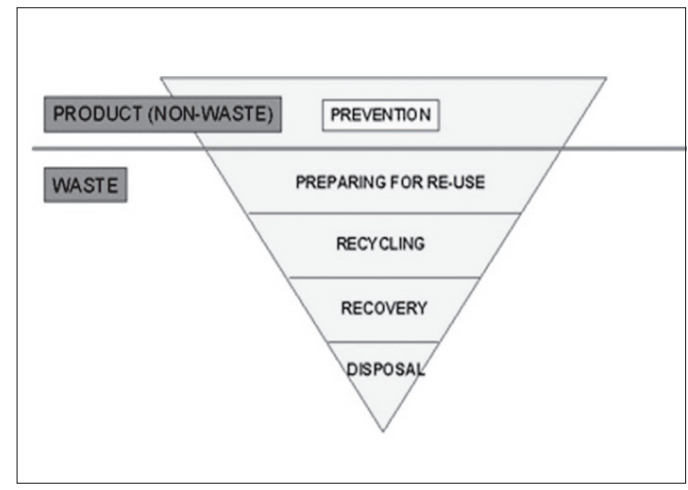

Source: European Commission (2016).

Also with regard to food losses and waste, a similar hierarchy has been defined by the High Level Panel of Experts on Food Security and Nutrition (HLPE). In fact, the HLPE invited to adopt measures to reduce food losses and waste (FLW), through a food-use-not-waste hierarchy, that is FLW prevention, reallocation of food as animal feed, food recycling for energy production through anaerobic digestion, food recovery for compost production, and ultimately, if no other solution is available, food disposal in landfills (HLPE, 2014).

The proposed qualitative indicator assesses the alignment of waste management practices at agricultural firm level with the waste management hierarchy with a particular reference to food losses and waste (Table 1; see also Supplementary material 5).

\subsubsection{Summary of themes, indices and indi- cators of environmental sustainability}

The environmental sustainability of a farm/ firm is calculated as the arithmetic average of the scores of four indices (agricultural biodiversity management, land use and management, energy use and climate change, use of chemical inputs) and one indicator (responsible management of production by-products and waste) (Table 1). All the indices and indicators have the same weight. An agricultural farm/firm, and consequently any of its products, is considered sustainable from the environmental point of view if it has an overall score equal to or higher than 5 . 
Table 1 - Environmental indicators, themes and indices.

\begin{tabular}{|c|c|c|c|}
\hline Indicators & Themes & $\begin{array}{c}\text { Environmental } \\
\text { sustainability } \\
\text { score component }\end{array}$ & Description \\
\hline Crop diversity (DC) & \multirow{11}{*}{ Biodiversity } & \multirow{11}{*}{$\begin{array}{l}\text { Agriculture } \\
\text { Biodiversity } \\
\text { Management } \\
\text { Index } \\
\text { ABMI = (DC + } \\
\mathrm{NSAA}+\mathrm{DCA} \\
+\mathrm{DCE}+\mathrm{PCC}+ \\
\mathrm{DCL}+\mathrm{GA}+\mathrm{SHS} \\
+\mathrm{DAV}+\mathrm{DV}) / 11\end{array}$} & \multirow{11}{*}{$\begin{array}{l}\text { Synthetic index that } \\
\text { assesses, through qualitative } \\
\text { and quantitative indicators, } \\
\text { the level of sustainability } \\
\text { in the management of the } \\
\text { biodiversity resource in } \\
\text { relation to the agronomic } \\
\text { practices of the agricultural } \\
\text { firm and to the spatial } \\
\text { organization choices of the } \\
\text { productive and not directly } \\
\text { productive areas at firm } \\
\text { level. }\end{array}$} \\
\hline $\begin{array}{l}\text { Number of farm animal species } \\
\text { (NSAA) }\end{array}$ & & & \\
\hline Tree plant density (DCA) & & & \\
\hline Herbaceous plant diversity (DCE) & & & \\
\hline Presence of cover crops (PCC) & & & \\
\hline Legume crop density (DCL) & & & \\
\hline Plot average area (GA) & & & \\
\hline Semi-natural habitat surface (SHS) & & & \\
\hline Duration of rotations (DAV) & & & \\
\hline $\begin{array}{l}\text { Diversity of crop varieties and animal } \\
\text { breeds (DVAB) }\end{array}$ & & & \\
\hline Varietal diversity (DV) & & & \\
\hline $\begin{array}{l}\text { Application of soil conservation and } \\
\text { improvement practices (SIP) }\end{array}$ & \multirow{5}{*}{$\begin{array}{l}\text { Land use and } \\
\text { management }\end{array}$} & \multirow{5}{*}{$\begin{array}{l}\text { Land } \\
\text { Management } \\
\text { Index } \\
\mathrm{LMI}=(\mathrm{SIP}+\mathrm{SEP} \\
+\mathrm{NFI}+\mathrm{PMI}+ \\
\mathrm{SCM}) / 5\end{array}$} & \multirow{5}{*}{$\begin{array}{l}\text { Index to assess the } \\
\text { sustainability in the use of } \\
\text { the soil resource and in the } \\
\text { agronomic practices related } \\
\text { to it through qualitative and } \\
\text { quantitative indicators }\end{array}$} \\
\hline Soil erosion protection (SEP) & & & \\
\hline Nitrogen fertilisers input (NFI) & & & \\
\hline $\begin{array}{l}\text { Input of plant protection products } \\
\text { (PMI) }\end{array}$ & & & \\
\hline Use of agricultural machinery (SCM) & & & \\
\hline Final Energy Consumption (FEC) & \multirow{6}{*}{$\begin{array}{l}\text { Energy use and } \\
\text { climate change }\end{array}$} & \multirow{6}{*}{$\begin{array}{l}\text { Energy Use Index } \\
\text { EUI }=(\text { FEC }+ \\
\mathrm{MFC}+\mathrm{LC}+\mathrm{PC} \\
+\mathrm{PMC}+\mathrm{FC}) / 6\end{array}$} & \multirow{6}{*}{$\begin{array}{l}\text { Index that assesses GHG } \\
\text { emissions at farm level }\end{array}$} \\
\hline $\begin{array}{l}\text { Mineral Fertilizers Consumption } \\
\text { (MFC) }\end{array}$ & & & \\
\hline Pesticide Consumption (PC) & & & \\
\hline Lubricant Consumption (LC) & & & \\
\hline Plastic Material Consumption (PMC) & & & \\
\hline Use of off-farm animal feeds (FC) & & & \\
\hline Nitrogen consumption (N-tot) & \multirow{5}{*}{$\begin{array}{l}\text { Use of } \\
\text { chemical inputs } \\
\text { (fertilisers, soil } \\
\text { amendments, } \\
\text { conditioners, } \\
\text { plant protection } \\
\text { products) }\end{array}$} & \multirow{5}{*}{$\begin{array}{l}\text { Total Chemical } \\
\text { Input } \\
\text { Consumption } \\
\text { TCIC }=(\text { N-tot } \\
+ \text { P-tot }+ \text { F-tot }+ \\
\text { Ins-tot }+ \text { Herb-tot }) \\
/ 5\end{array}$} & \multirow{5}{*}{$\begin{array}{l}\text { Index that assesses the } \\
\text { sustainability of the use of } \\
\text { chemical inputs (fertilizers, } \\
\text { pesticides, etc.) that end } \\
\text { up in the soil, air and } \\
\text { groundwater. }\end{array}$} \\
\hline $\begin{array}{l}\text { Use of total phosphorus pentoxide } \\
\left(\mathrm{P}_{2} \mathrm{O}_{5}\right) \text { (P-tot) }\end{array}$ & & & \\
\hline Use of fungicides (F-tot) & & & \\
\hline $\begin{array}{l}\text { Use of insecticides and acaricides } \\
\text { (Ins-tot) }\end{array}$ & & & \\
\hline Use of herbicides (Herb-tot) & & & \\
\hline $\begin{array}{l}\text { Methods for the management of } \\
\text { production by-products and waste }\end{array}$ & \begin{tabular}{|l|} 
Responsible \\
management \\
of production \\
by-products and \\
waste \\
\end{tabular} & $\begin{array}{l}\text { Waste } \\
\text { management } \\
(\mathrm{WM})\end{array}$ & $\begin{array}{l}\text { Qualitative indicator } \\
\text { on sustainability in the } \\
\text { management of production } \\
\text { waste and by-products at the } \\
\text { level of the agri-food firm }\end{array}$ \\
\hline nability & $\mathrm{MI}+\mathrm{LMI}+\mathrm{EUI}$ & $\mathrm{I}+\mathrm{TCIC}+\mathrm{WM})$ & \\
\hline
\end{tabular}




\subsection{Discussion: From an environmental sustainability assessment approach to a sustainability certification scheme}

The methodological approach and set of indicators on agriculture environmental sustainability proposed in the present paper address three out of the five thematic areas (climate change, soil health, water, land conversion and its impacts on terrestrial ecosystems, and pollution) suggested by Reytar et al. (2014) namely climate change, soil health, and pollution (fertilisers, pesticides). As previously explained, the reason for it stays in the need for addressing main issues that matter at farm level, therefore, it can be argued that the impacts of land conversion are not as relevant in the Apulian context as it might be in other regions such as Latin America and South-East Asia, at least at the level of intervention focussed on by the certification scheme, where indicators on biodiversity address, at least indirectly, impacts of habitat conversion. The indicator set doesn't address water, and this can be a weakness of the approach that should be addressed given the central role of water in the Mediterranean context. The reason of this lack is in the impossibility to monitor in a really effective way, the rational use of water, as well as the causes impairing its quality, in relation to the specific requirements due to the different crops and microclimatic conditions of the Apulian companies. Nevertheless, referring to Reytar et al. (2014), the proposed approach also deals with waste management and expands the coverage of themes relating to pollution caused by agricultural activities and practices.

Besides, a growing challenge to sustainability is to balance benefits and trade-offs that result from agriculture (FAO, 2014a). The proposed approach, in order to consider possible trade-offs along the supply chain, addresses several phases of the life cycles of typical products. However, on the conceptual level, contrary to LCA-based methods, where the cradle phase is associated with mineral resources extraction, the focus is on the territorial agro-system environment as the cradle where farming takes place. The reason for such a choice is that environmental quality and performance of typical products depend on the linkage of the producers with the natural environment and on the quality of land-based resources (soils, biodiversity, water, climate).

It is increasingly being recognised that for environmental labels and information schemes (ELIS) to be effective in achieving the Sustainable Development Goals (SDGs), they need to address a product from a life-cycle approach (UNEP, 2015). From a methodological perspective, the adopted approach generalises and expands LCA as far as aggregation of indicators into composite indexes is concerned. In practice, many ELIS are based on LCA, a modelling methodology that still presents many criticalities in its accuracy and stringency aspects, especially when applied to food products; the modelling of LCA is based on Input/Output (I/O) analysis, which encodes an industrially-biased approach that is decoupled from limited territorial worldview of food systems (Stefanova \& Iannetta, 2016). This makes such schemes conceptually not appropriate for communicating environmental performance of typical food products, which is rooted in their ability to use and conserve territorial natural resources. Moreover, various international efforts in the last 15-20 years to address biodiversity impacts and resources in LCA modelling framework have not yielded scientifically sound ways of doing so. On the other hand, it is increasingly recognised the functional role that biodiversity plays in provisioning of different levels and types of ecosystem services, which re-connect farmers in a close relation with local natural systems. Furthermore, LCA-based methods are more appropriate for production contexts, which can assure economy of scale, through which the cost of LCA consultancy services can be absorbed without compromising the quality of the food products. On the opposite, producers of typical products are often limited in scale, as they rely on local natural and social resources, and grow only when such territorial limits allow it (Fonte, 2006; van der Ploeg et al., 2009).

The methodological approach and the related scoring system presented in this paper allow expressing in a simple, objective and numerical way the environmental sustainability of a product and/or the performance of the firm produc- 
Figure 2 - Sustainability logo.

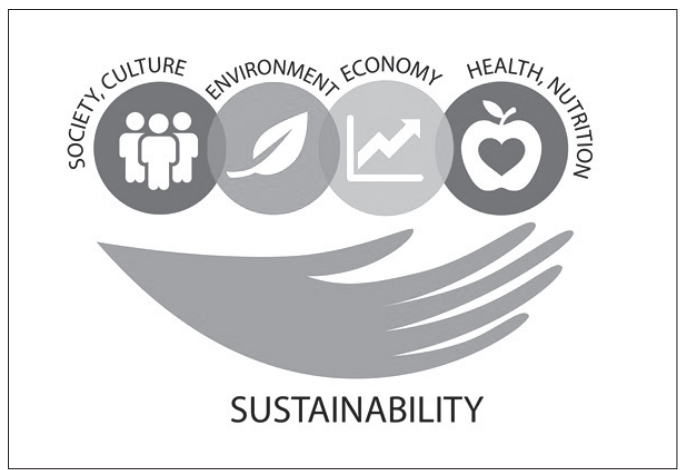

ing it. The main objective of the approach for the assessment of environmental performance of Apulian agricultural companies and agro-food products is to draft guidelines on the sustainability of typical products that serve for developing a sustainability certification scheme at regional level; with a sustainability standard and a sustainability $\operatorname{logo}$ (Figure 2) approved by the Apulia Region Authority. The rationale behind the planned product sustainability certification scheme is trifold:

4. In the short term, it is intended to inform consumers on environmental performances of the supply chains. Despite information on negative impacts on the environment (and their potential reductions through lower numeric values calculated as environmental footprints), consumers require also information on producers who add value to the environment in which they operate, through practices that protect soil, local biodiversity and landscape, avoid the use of substances with negative effects on both ecosystems and human health, limit negative effects on climate and on the use of non-renewable resources.

5. In the mid-term, since the introduction of a sustainability management system in an agrifood chain is only a starting point, it is important to envisage continual improvement; this means launching a virtuous process leading to an overall approach to sustainability for the Apulian agri-food firms applying the methodological approach outlined in this paper. The defined sustainability criteria and themes, following the principle of continual improvement, are continuously monitored to enable the assessment of the benchmark values. Sustainability benchmark and reference values defined in the sustainability standard will be updated every five years.

6. In the long term, its main function is to serve as a basis for the implementation of environmental management system, which informs value chain actors on the environmental performances of their activities as well as on the root causes of underperformances, in such a way that such information could be used in triggering collective action for achieving scaling up of positive impacts.

\section{Conclusions}

The paper presents an approach for the assessment of the environmental performance of the Apulian typical products. The presented approach has several strengths; basic indicators are measurable and simple, indicators are aggregated into composite indices that consider the specificities of the environmental pillar of sustainability, indicator benchmarks are dynamic. The approach is also both robust and user friendly. It is based on the last scientific developments regarding the assessment of environmental sustainability in agriculture and food systems. It is also user friendly as it allows farmers to assess the sustainability of their own farms and products using a straightforward 10 -point scoring scale. This also allows an easy communication on environmental performance to consumers and policy makers alike. Another strength of the approach described in the paper is that it is linked to the regional quality scheme thus allowing to connect quality and sustainability. The proposed approach can be used standalone or integrated with economic, socio-cultural and nutrition-health indicators to get a holistic model for the assessment of agro-food products sustainability. For all the above-mentioned reasons, the approach has the potential to be used also on non-typical agro-food products in Apulia and Italy and, with due adjustments of thresholds/benchmarks and scoring scales, to be replicated in other territories in the Mediterranean area and beyond. Nevertheless, further work is needed to refine the approach especially regarding the values of sustainabil- 
ity thresholds and benchmarks in order to contribute to a continuous improvement in Apulian farms that is, eventually, leading to a genuine transition towards sustainability in the regional agro-food system. Further consideration is also needed to improve the coverage of the approach especially in relation to the management of water resources in Apulian farms and agricultural companies. Additional research will be required to better understand whether the proposed information on environmental sustainability will be also salient to future consumers.

\section{References}

Apulia Region, 2010. Atlas of Typical Agri-Food Products of Apulia. Bari: Regione Puglia.

Apulia Region Authority, 2013. Il contesto socioeconomico dell'agricoltura e dei territori rurali della Puglia. Bari: Assessorato alle Risorse Agroalimentari, Regione Puglia.

Azzini E., Maiani G., Turrini A., Intorre F., Lo Feudo G., Capone R., Bottalico F., El Bilali H., Polito A., 2018. The health-nutrition dimension: a methodological approach to assess the nutritional sustainability of typical agro-food products and the Mediterranean diet. Journal of the Science of Food and Agriculture, 98(10): 3684-3705, https://doi. org/10.1002/jsfa.8877.

Brentrup F., Küsters J., Kuhlmann H., Lammel J., 2004. Environmental impact assessment of agricultural production systems using the life cycle assessment methodology. European Journal of Agronomy, 20(3): 247-264, https://doi.org/10.1016/ S1161-0301(03)00024-8.

Brunori G., Galli F., Barjolle D., van Broekhuizen R., Colombo L., Giampietro M., Kirwan J., Lang T., Mathijs E., Maye D., de Roest K., Rougoor C., Schwarz J., Schmitt E., Smith J., Stojanovic Z., Tisenkopfs T., Touzard J.-M., 2016. Are Local Food Chains More Sustainable than Global Food Chains? Considerations for Assessment. Sustainability, 8(5): 449, https://doi.org/10.3390/su8050449.

Calabrese G., Abdelatif O.M., Perrino E.V., 2016. Correlations between Organic and Conventional Management, on-Field Biodiversity and Landscape Diversity, in Olive Groves in Apulia (Italy). $A d$ vances in Plants and Agriculture Research, 5(4): 20, https://doi.org/10.15406/apar.2016.05.00187

Calabrese G., Perrino E.V., Ladisa G., Aly A., Tesfmichael Solomon M., Mazdaric S., Benedetti A., Ceglie F.G., 2015. Short-term effects of different soil management practices on biodiversity and soil quality of Mediterranean ancient olive orchards. Organic Agriculture, 5(3): 209-223, https://doi. org/10.1007/s13165-015-0120-8.

Capone R., Bottalico F., Driouech N., El Bilali H., Cardone G., Debs P., 2017. Typical Products Sustainability in Southern Italy: Exploring Apulian Consumer Perception. In: Proceedings of the 2nd International Forum on Agri-Food Logistics "Logistics Facing Challenges of Food Security and Environmental Protection”, Poznan (Poland), 21 23 June. Poznan: Poznan University of Life Sciences, pp. 32-36.

Capone R., El Bilali H., Bottalico F., 2016. Assessing the Sustainability of Typical Agro-Food Products: Insights from Apulia Region, Italy. New Medit, 15(1): 28-35.

Capone R., Malorgio G., Cardone G., El Bilali H., Bottalico F., Debs P., 2016. Towards a common understanding of agro-food products economic sustainability: insights from Apulia region, Italy. In: Book of Abstracts, 158th EAAE Seminar "Euro-Mediterranean Cooperation in Sustainable Agriculture and Food Security: Policies, Sustainability, Marketing and Trade", Chania, Greece, 08-09 September. pp. 10-11. Retrieved from http://158eaae.maich.gr/ docs/158eaae_abstracts_book.pdf.

Caporali F., Mancinelli R., Campiglia E., 2003. Indicators of Cropping System Diversity in Organic and Conventional Farms in Central Italy. International Journal of Agricultural Sustainability, 1(1): 67-72, https://doi.org/10.3763/ijas.2003.0107.

Chaudhary A., Gustafson D., Mathys A., 2018. Multi-indicator sustainability assessment of global food systems. Nature Communications, 9(1): 848, https://doi.org/10.1038/s41467-018-03308-7

Delbaere B., Nieto Serradilla A., 2004. Environmental risks from agriculture in Europe: Locating environmental risk zones in Europe using agri-environmental indicators. Tilburg: ECNC-European Centre for Nature conservation.

Dernini S., Meybeck A., Burlingame B., Gitz V., Lacirignola C., Debs P., Capone R., El Bilali H., 2013. Developing a methodological approach for assessing the sustainability of diets: The Mediterranean diet as a case study. New Medit, 12(3): 28-36.

Dubey A., Lal R., 2009. Carbon Footprint and Sustainability of Agricultural Production Systems in Punjab, India, and Ohio, USA. Journal of Crop Improvement, 23(4): 332-350, https://oi. org/10.1080/15427520902969906.

Dulja X., Calabrese J., Pacini C.C.V., Nikolla M., 2013. Sustainability Comparison Between Organ- 
ic and Conventional Systems at Farm and Field Scale: A Case Study in Olive Production Systems in Apulia Region. European Journal of Sustainable Development, 2(4): 19-36. Retrieved from https:// ecsdev.org/ojs/index.php/ejsd/article/view/77/71.

El Bilali H., 2019. Research on agro-food sustainability transitions: A systematic review of research themes and an analysis of research gaps. Journal of Cleaner Production, 221: 353-364, https://doi. org/10.1016/j.jclepro.2019.02.232.

Eriksson I. S., Elmquist H., Nybrant T., 2005. SALSA: A Simulation Tool to Assess Ecological Sustainability of Agricultural Production. AMBIO: A Journal of the Human Environment, 34(4): 388392, https://doi.org/10.1579/0044-7447-34.4.388.

European Commission, 2006a. Proposal for a Directive of the European Parliament and of the Council establishing a framework for the protection of soil and amending Directive 2004/35/EC. Brussels. Retrieved from https://eur-lex.europa.eu/legal-content/EN/TXT/PDF/?uri=CELEX:52006PC0232\&from $=\mathrm{EN}$.

European Commission, 2006b. Thematic Strategy for Soil Protection. Communication from the Commission to the Council, the European Parliament, the European Economic and Social Committee and The Committee of the Regions COM(2006)231. Brussels. Retrieved from https://eur-lex.europa.eu/legal-content/EN/TXT/PDF/?uri=CELEX:52006DC0231\& from $=\mathrm{EN}$.

European Commission, 2012. The implementation of the Soil Thematic Strategy and ongoing activities. Report from the Commission to the European Parliament, the Council, the European Economic and Social Committee and the Committee of the Regions. Brussels. Retrieved from https://eur-lex. europa.eu/legal-content/EN/TXT/PDF/?uri=CELEX:52012DC0046\& from $=E N$.

European Commission, 2015. Glossary of terms related to the Common Agricultural Policy. Retrieved May 14, 2019, from https://ec.europa.eu/info/ food-farming-fisheries_en.

European Commission, 2016. Directive 2008/98/EC on waste (Waste Framework Directive). Retrieved April 18, 2019, from http://ec.europa.eu/environment/waste/framework.

FAO, 2013. Sustainability Assessment of Food and Agricultural System: indicators. Rome: FAO. http://www.fao.org/fileadmin/templates/nr/sustainability_pathways/docs/SAFA_Indicators_final 19122013.pdf.

FAO, 2014a. Building a common vision for sustainable food and agriculture - Principles and Ap- proaches. Rome: FAO. http://www.fao.org/3/ai3940e.pdf.

FAO, 2014b. Developing sustainable food value chains - Guiding principles. Rome: FAO. Retrieved from http://www.fao.org/3/a-i3953e.pdf.

Fonte M., 2006. Slow Food's Presidia: What do Small Producers do with Big Retailers? Research in Rural Sociology and Development, 12: 203-240, https:// doi.org/10.1016/S1057-1922(06)12009-0.

Friedmann H., Mcnair A., 2008. Whose Rules Rule? Contested Projects to Certify 'Local Production for Distant Consumers.' Journal of Agrarian Change, 8(2-3): 408-434, https://doi. org/10.1111/j.1471-0366.2008.00175.x.

Garnett T., 2014. Three perspectives on sustainable food security: efficiency, demand restraint, food system transformation. What role for life cycle assessment? Journal of Cleaner Production, 73: 1018, https://doi.org/10.1016/j.jclepro.2013.07.045.

Gruère G., 2013. A Characterisation of Environmental Labelling and Information Schemes. Paris: OECD Publishing (OECD Environment Working Papers, no. 62), https://doi.org/10.1787/5k3z11hpdgq2-en.

HLPE, 2014. Food Losses and Waste in the Context of Sustainable Food Systems. A Report by the High Level Panel of Experts on Food Security and Nutrition (HLPE) of the Committee on World Food Security. Rome. Retrieved from http://www.fao. org/3/a-i3901e.pdf

IOBC, 2004. Ecological Infrastructures - Ideabook on Functional Biodiversity at the farm level. Lindau: LBL.

Lacirignola C., Dernini S., Capone R., Meybeck A., Burlingame B., Gitz V., El Bilali H., Debs P., Belsanti V., 2012. Towards the Development of Guidelines for Improving the Sustainability of Diets and Food Consumption Patterns: The Mediterranean Diet as a Pilot Study. Bari: CIHEAM (Options méditerranéennes, Series B, 70). Retrieved from http://om.ciheam.org/om/pdf/b70 (en)/b70 (en).pdf

Latruffe L., Diazabakana A., Bockstaller C., Desjeux Y., Finn J., Kelly E., Ryan M., Uthes S., 2016. Measurement of sustainability in agriculture: a review of indicators. Studies in Agricultural Economics, 118(3): 123-130, https://doi.org/10.7896/j.1624.

Mackey B., Prentice I.C., Steffen W., House J.I., Lindenmayer D., Keith H., Berry S., 2013. Untangling the confusion around land carbon science and climate change mitigation policy. Nature Climate Change, 3(6): 552-557, https://doi.org/10.1038/ nclimate1804. 
Marsden T., 2013. Sustainable place-making for sustainability science: the contested case of agri-food and urban-rural relations. Sustainability Science, 8(2): 213-226, https://doi.org/10.1007/s11625-012-0186-0.

Mekonnen M.M., Hoekstra A.Y., 2012. A Global Assessment of the Water Footprint of Farm Animal Products. Ecosystems, 15(3): 401-415, https://doi. org/10.1007/s10021-011-9517-8.

MiPAAF, 2013. Tredicesima revisione dell'elenco dei prodotti agroalimentari tradizionali [Thirteenth edition of the list of traditional food products]. Rome: Ministero delle politiche agricole alimentari e forestali.

MiPAAFT, 2019. Diciannovesima revisione dell'elenco dei prodotti agroalimentari tradizionali. Rome. Retrieved from https://www.politicheagricole.it/ flex/cm/pages/ServeAttachment.php/L/IT/D/6\%2 52F9\%252Fe\%252FD.57c91e29f75933c85412/P/ BLOB\%3AID\%3D13762/E/xlsx.

Moscatelli S., Gamboni M., Dernini S., Capone R., El Bilali H., Bottalico F., Debs P., Cardone G., 2017. Exploring the Socio-cultural Sustainability of Traditional and Typical Agro-food Products: Case study of Apulia Region, South-eastern Italy. Journal of Food and Nutrition Research, 5(1): 6-14, https://doi.org/10.12691/jfnr-5-1-2.

Naderi Mahdei K., Bahrami A., Aazami M., Sheklabadi M., 2015. Assessment of agricultural farming systems sustainability in Hamedan province using ecological footprint analysis (case study: Irrigated wheat). Journal of Agricultural Science and Technology, 17: 1409-1420.

Poppe K., Vrolijk H., Dolman M., Silvis H., 2016. FLINT - Farm-level Indicators for New Topics in policy evaluation: an introduction. Studies in $\mathrm{Ag}$ ricultural Economics, 118(3): 116-122, https://doi. org/10.7896/j.1627.

Prag A., Lyon T., Russillo A., 2016. Multiplication of Environmental Labelling and Information Schemes
(ELIS) - Implications for Environment and Trade. Paris: OECD Publishing (OECD Environment Working Papers, no. 106), https://doi.org/10.1787/ 5jm0p33z27wf-en.

Reytar K., Hanson C., Henninger N., 2014. Indicators of Sustainable Agriculture: A Scoping Analysis. Working Paper, Installment 6 of "Creating a Sustainable Food Future". Washington DC: World Resources Institute.

Stefanova M., Iannetta M., 2016. On the use of LCA indicators for the environmental assessment of food systems: the case study of the Mediterranean diet. In: Wilcox A., Vinal S. (eds.), Social and technological transformation of farming systems: diverging and converging pathways. Proceedings of the 12th European IFSA Symposium, Newport Harper Adams University, 12-15 July, vol. 2, pp. 14161429. Retrieved from http://www.ifsa-europe.org.

Talukder B., 2016. Multi-Criteria Decision Analysis (MCDA) for Agricultural Sustainability Assessment. Wilfrid Laurier University, Waterloo (Canada). Retrieved from http://scholars.wlu.ca/etd/1838.

UNEP, 2015. Product Sustainability Information - State of Play and Way Forward. Paris: UNEP. https://wedocs.unep.org/bitstream/ handle/20.500.11822/9725/-Product_Sustainability_Information_State_of_Play_and_Way_ Forward-2015Product_Sustainability.pdf.pdf? sequence $=3 \& \mathrm{amp} \% 3$ BisAllowed $=$

UNFSS, 2016. Meeting Sustainability Goals - Voluntary sustainability standards and the role of the government. Geneva. Retrieved from https:/unctad.org/en/PublicationsLibrary/unfss_2nd_2016 en.pdf.

van der Ploeg J. D., Laurent C., Blondeau F., Bonnafous P., 2009. Farm diversity, classification schemes and multifunctionality. Journal of Environmental Management, 90: S124-S131, https://doi.org/10.1016/j. jenvman.2008.11.022. 


\section{Supplementary materials}

Supplementary material 1 - Indicators relating to agriculture biodiversity theme.

\begin{tabular}{|c|c|c|c|c|c|c|c|c|c|c|c|c|c|c|}
\hline 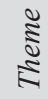 & Indicators & $\begin{array}{l}\text { Description } \\
\text { of indicators }\end{array}$ & \multicolumn{12}{|c|}{$\begin{array}{l}\text { Calculation methods (if applicable), } \\
\text { thresholds and scoring scales }\end{array}$} \\
\hline \multirow{30}{*}{ 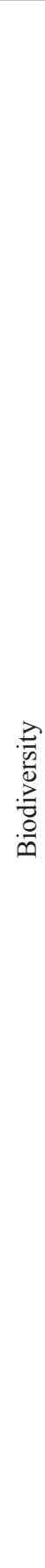 } & \multirow[t]{3}{*}{$\begin{array}{l}\text { Crop diversity } \\
\text { (DC) }\end{array}$} & \multirow{3}{*}{$\begin{array}{l}\text { This indicator, referring to } \\
\text { the number of cultivated } \\
\text { plant species, aims to assess } \\
\text { on-farm crop diversification } \\
\text { practices, meant as a } \\
\text { sustainable alternative to } \\
\text { mono-cropping }\end{array}$} & \multicolumn{12}{|c|}{$\begin{array}{l}\text { Number of plant species grown on the farm. } \\
\text { DC = } 1 \text { i.e. monoculture. } \\
\text { Scoring scale: }\end{array}$} \\
\hline & & & U & 1 & 2 & 3 & 4 & 5 & 6 & 7 & 8 & 9 & 10 & $>10$ \\
\hline & & & $\begin{array}{l}0 \\
\tilde{0} \\
\tilde{L}\end{array}$ & 1 & 2 & 3 & 4 & 5 & 6 & 7 & 8 & 9 & 10 & 10 \\
\hline & \multirow{3}{*}{$\begin{array}{l}\text { Number of } \\
\text { farm animal } \\
\text { species } \\
\text { (NSAA) }\end{array}$} & \multirow{3}{*}{$\begin{array}{l}\text { This indicator aims to assess } \\
\text { the diversification of on-farm } \\
\text { bred species, which enable } \\
\text { the optimisation of production } \\
\text { processes, the upgrading of by- } \\
\text { products, and the improvement } \\
\text { of biodiversity associated with } \\
\text { production processes. }\end{array}$} & \multicolumn{12}{|c|}{$\begin{array}{l}\text { Number of animal species reared on the farm for } \\
\text { production purposes. } \\
\text { Scoring scale: }\end{array}$} \\
\hline & & & U & 1 & 2 & 3 & 4 & 5 & 6 & 7 & 8 & 9 & 10 & $>10$ \\
\hline & & & 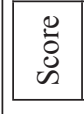 & 1 & 2 & 3 & 4 & 5 & 6 & 7 & 8 & 9 & 10 & 10 \\
\hline & \multirow{12}{*}{$\begin{array}{l}\text { Tree plant } \\
\text { density (DCA) }\end{array}$} & \multirow{12}{*}{$\begin{array}{l}\text { Ratio of the number of } \\
\text { plots grown with tree plants } \\
\left(\mathrm{UAA}_{\text {arb }}\right) \text { to the farm utilized } \\
\text { agricultural area }\left(\mathrm{UAA}_{\text {tot }}\right)\end{array}$} & \multicolumn{12}{|c|}{$\begin{array}{l}\mathrm{DCA}=\mathrm{UAA}_{\text {arb }} \times \mathrm{UAA}_{\text {tot }^{-1}} \\
\text { Scoring scale: }\end{array}$} \\
\hline & & & \multicolumn{6}{|c|}{$\operatorname{DCA}(\%)$} & \multicolumn{6}{|c|}{ Score } \\
\hline & & & \multicolumn{6}{|c|}{\begin{tabular}{|l|}
$\mathrm{DCA}<10$ \\
\end{tabular}} & \multicolumn{6}{|c|}{1} \\
\hline & & & \multicolumn{6}{|c|}{$10<\mathrm{DCA}<20$} & \multicolumn{6}{|c|}{3} \\
\hline & & & \multicolumn{6}{|c|}{$20<$ DCA $<30$} & \multicolumn{6}{|c|}{5} \\
\hline & & & \multicolumn{6}{|c|}{$30<\mathrm{DCA}<40$} & \multicolumn{6}{|c|}{8} \\
\hline & & & \multicolumn{6}{|c|}{$40<\mathrm{DCA}<50$} & \multicolumn{6}{|c|}{10} \\
\hline & & & \multicolumn{6}{|c|}{$50<$ DCA $<60$} & \multicolumn{6}{|c|}{9} \\
\hline & & & $60<$ & $\mathrm{DC}$ & $1<$ & & & & & & & 8 & & \\
\hline & & & $70<$ & $\mathrm{DC}$ & $1<$ & & & & & & & 7 & & \\
\hline & & & $80<$ & $\mathrm{DC}$ & $1<$ & & & & & & & 6 & & \\
\hline & & & $90<$ & $\mathrm{DC}$ & $1<$ & 100 & & & & & & 5 & & \\
\hline & & & $\begin{array}{l}\text { DCE } \\
\text { Scorin }\end{array}$ & $\begin{array}{l}=\mathrm{U} \\
\mathrm{gg} \mathrm{sC}\end{array}$ & & & & & & & & & & \\
\hline & & & DCE & $(\%)$ & & & & & & & & score & & \\
\hline & & & DCE & $<1$ & & & & & & & & 5 & & \\
\hline & Herbaceous & Ratio of the number of plots & $10<$ & $\mathrm{DCl}$ & $<$ & & & & & & & 6 & & \\
\hline & plant diversity & grown with herbaceous plants & $20<$ & $\mathrm{DCl}$ & $<<$ & & & & & & & 8 & & \\
\hline & $(\mathrm{DCE})$ & $\left(\mathrm{UAA}_{\mathrm{erb}}\right)$ within the farm to & $30<$ & $\mathrm{DCl}$ & $<$ & & & & & & & 9 & & \\
\hline & & the utilized agricultural area & $40<$ & $\mathrm{DCI}$ & $<$ & & & & & & & 10 & & \\
\hline & & $\left(\mathrm{UAA}_{\mathrm{tot}}\right)$ & $50<$ & $\mathrm{DCl}$ & $<$ & & & & & & & 8 & & \\
\hline & & & $60<$ & $\mathrm{DCl}$ & $<<$ & & & & & & & 7 & & \\
\hline & & & $70<$ & $\mathrm{DCI}$ & $<$ & & & & & & & 5 & & \\
\hline & & & $80<$ & $\mathrm{DCl}$ & $<<$ & & & & & & & 2 & & \\
\hline & & & $90<$ & $\mathrm{DCl}$ & $<$ & 100 & & & & & & 1 & & \\
\hline
\end{tabular}




\begin{tabular}{|c|c|c|c|c|}
\hline$\frac{\sqrt{2}}{\tilde{\Xi}}$ & Indicators & $\begin{array}{l}\text { Description } \\
\text { of indicators }\end{array}$ & \multicolumn{2}{|c|}{$\begin{array}{c}\text { Calculation methods (if applicable), } \\
\text { thresholds and scoring scales }\end{array}$} \\
\hline \multirow{35}{*}{ 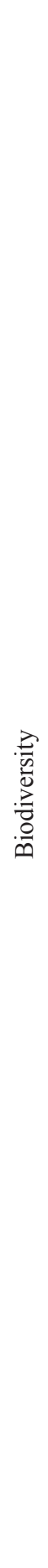 } & \multirow{12}{*}{$\begin{array}{l}\text { Presence of } \\
\text { cover crops } \\
(\mathrm{PCC})\end{array}$} & \multirow{12}{*}{$\begin{array}{l}\text { Weighted average of cover } \\
\text { crops as related to the UAA, } \\
\text { excluding the set-aside area }\end{array}$} & \multicolumn{2}{|c|}{$\begin{array}{l}\text { The duration of the presence of cover crops in the } \\
\text { field }(\mathrm{t}) \text { is calculated referring to one year (e.g. days } \\
\text { / } 365 \text {; months / 12) and weighted on the basis of the } \\
\text { agricultural area (e.g. UAAcover crop / UAAtot). } \\
\text { PCC }=\sum_{\mathrm{i}=1}^{\mathrm{n}} \frac{\text { SAUcov crop }}{\text { SAUtot }} \mathrm{t}_{\mathrm{i}} \\
\text { Scoring scale: }\end{array}$} \\
\hline & & & PCC (\%) & Score \\
\hline & & & No cover crop & 1 \\
\hline & & & $\mathrm{PCC}<5$ & 2 \\
\hline & & & $5<$ PCC $<15$ & 3 \\
\hline & & & $15<$ PCC $<25$ & 4 \\
\hline & & & $25<\mathrm{PCC}<35$ & 5 \\
\hline & & & $35<\mathrm{PCC}<45$ & 6 \\
\hline & & & $45<\mathrm{PCC}<55$ & 7 \\
\hline & & & $55<\mathrm{PCC}<70$ & 8 \\
\hline & & & $70<\mathrm{PCC}<85$ & 9 \\
\hline & & & $85<\mathrm{PCC}<100$ & 100 \\
\hline & \multirow{12}{*}{$\begin{array}{l}\text { Legume crop } \\
\text { density (DCL) }\end{array}$} & \multirow{12}{*}{$\begin{array}{l}\text { Ratio of the number of plots } \\
\text { with legumes }\left(\mathrm{UAA}_{\mathrm{leg}}\right) \text { to the } \\
\text { farm utilized agricultural area } \\
\left(\mathrm{UAA}_{\text {tot }}\right)\end{array}$} & \multicolumn{2}{|l|}{$\begin{array}{l}\mathrm{DCL}=\mathrm{UAA}_{\operatorname{leg}} \times \mathrm{UAA}_{\text {tot }}{ }^{-1} \\
\text { Scoring scale: }\end{array}$} \\
\hline & & & \begin{tabular}{|l|} 
DCL $(\%)$ \\
\end{tabular} & Score \\
\hline & & & DCL $<10$ & 5 \\
\hline & & & $10<\mathrm{DCL}<20$ & 6 \\
\hline & & & $20<\mathrm{DCL}<30$ & 8 \\
\hline & & & $30<\mathrm{DCL}<40$ & 9 \\
\hline & & & $40<\mathrm{DCL}<50$ & 10 \\
\hline & & & $50<\mathrm{DCL}<60$ & 8 \\
\hline & & & $60<\mathrm{DCL}<70$ & 7 \\
\hline & & & $70<\mathrm{DCL}<80$ & 5 \\
\hline & & & $80<\mathrm{DCL}<90$ & 2 \\
\hline & & & $90<$ DCL $<100$ & 1 \\
\hline & \multirow{11}{*}{$\begin{array}{l}\text { Plot average } \\
\text { area (GA) }\end{array}$} & \multirow{11}{*}{ Mean size of farm plots } & \multicolumn{2}{|l|}{$\begin{array}{l}\mathrm{GA}=\frac{\text { UAAtot }}{\text { Number of plots }} \\
\text { Scoring scale: }\end{array}$} \\
\hline & & & GA (ha) & Score \\
\hline & & & GA $<1$ & 1 \\
\hline & & & $\mathrm{GA}=1$ & 5 \\
\hline & & & $1.1<\mathrm{GA}<2$ & 8 \\
\hline & & & $2.1<\mathrm{GA}<3$ & 9 \\
\hline & & & $3<\mathrm{GA}<3.9$ & 10 \\
\hline & & & $4<\mathrm{GA}<4.9$ & 9 \\
\hline & & & $5<\mathrm{GA}<5.9$ & 8 \\
\hline & & & $6<\mathrm{GA}<6.9$ & 5 \\
\hline & & & $\mathrm{GA}>7$ & 1 \\
\hline
\end{tabular}




\begin{tabular}{|c|c|c|c|c|c|c|c|c|c|}
\hline $\begin{array}{l}\text { है } \\
\text { है }\end{array}$ & Indicators & $\begin{array}{l}\text { Description } \\
\text { of indicators }\end{array}$ & \multicolumn{7}{|c|}{$\begin{array}{l}\text { Calculation methods (if applicable), } \\
\text { thresholds and scoring scales }\end{array}$} \\
\hline \multirow{27}{*}{ 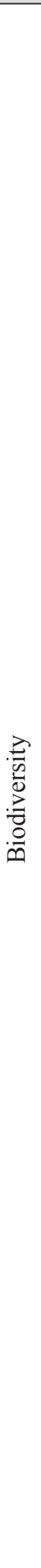 } & \multirow{12}{*}{$\begin{array}{l}\text { Semi-natural } \\
\text { habitat surface } \\
\text { (SHS or } \\
\text { EFAs) }\end{array}$} & \multirow{12}{*}{$\begin{array}{l}\text { Percentage of semi-natural } \\
\text { habitat surface (SUP } \\
\text { ecological focus areas (EFAs) } \\
\text { over the total farm area } \\
\text { (TFA) }\end{array}$} & \multicolumn{7}{|c|}{$\begin{array}{l}\text { SHS }=\frac{\sum_{\mathrm{i}=1}^{\mathrm{n}} \text { SUPSHS }}{\text { TFA }} \\
\text { Scoring scale: }\end{array}$} \\
\hline & & & \multirow{2}{*}{\multicolumn{3}{|c|}{\begin{tabular}{||l|} 
SHS $(\%)$ \\
SHS $<10$ \\
\end{tabular}}} & \multicolumn{4}{|c|}{ Score } \\
\hline & & & & & & \multicolumn{4}{|c|}{1} \\
\hline & & & \multicolumn{3}{|c|}{$10<$ SHS $<20$} & \multicolumn{4}{|c|}{2} \\
\hline & & & \multicolumn{3}{|c|}{$20<$ SHS $<30$} & \multicolumn{4}{|c|}{3} \\
\hline & & & \multicolumn{3}{|c|}{$30<$ SHS $<40$} & \multicolumn{4}{|c|}{4} \\
\hline & & & \multicolumn{3}{|c|}{$40<$ SHS $<50$} & \multicolumn{4}{|c|}{5} \\
\hline & & & \multicolumn{3}{|c|}{$50<$ SHS $<60$} & \multicolumn{4}{|c|}{6} \\
\hline & & & \multicolumn{3}{|c|}{$60<$ SHS $<70$} & \multicolumn{4}{|c|}{7} \\
\hline & & & \multicolumn{3}{|c|}{\begin{tabular}{|l|l}
$70<$ SHS $<80$ \\
\end{tabular}} & \multicolumn{4}{|c|}{8} \\
\hline & & & \multicolumn{3}{|c|}{$80<$ SHS $<90$} & \multicolumn{4}{|c|}{9} \\
\hline & & & \multicolumn{3}{|c|}{$90<$ SHS $<100$} & \multicolumn{4}{|c|}{10} \\
\hline & \multirow{12}{*}{$\begin{array}{l}\text { Duration } \\
\text { of rotations } \\
\text { (DAV) }\end{array}$} & \multirow{12}{*}{$\begin{array}{l}\text { Number of years of the } \\
\text { rotation of existing farm } \\
\text { crops, excluding set-aside } \\
\text { area }\end{array}$} & \multicolumn{7}{|c|}{$\begin{array}{l}\text { Weighted average of the number of years of } \\
\text { rotation on arable land plots, excluding set-aside } \\
\text { areas. } \\
\text { The presence of crops in the plot }(\mathrm{t}) \text { is calculated } \\
\text { referring to one year (e.g. days / } 365 \text {; months / 12) } \\
\text { and weighted on the basis of the land area (e.g. } \\
\text { UAAcrop / UAA } A_{\text {tot }} \text { ). } \\
\text { DAV }=\sum_{\mathrm{i}=1}^{\mathrm{n}} \mathrm{t}_{\mathrm{i}} \frac{\text { SAUi }}{\text { SAUtot }} \\
\text { Scoring scale: }\end{array}$} \\
\hline & & & DAV & & & & & & \\
\hline & & & \begin{tabular}{|l|} 
No rot \\
\end{tabular} & $n / 1$ & locu & & & & \\
\hline & & & DAV & mon & & & & & \\
\hline & & & $6 \mathrm{mon}$ & $<\mathrm{D}$ & $<9$ & ath & & & \\
\hline & & & $9 \mathrm{mon}$ & $<\mathrm{D}$ & $<1$ & & & & \\
\hline & & & 1 year & $\mathrm{AV}$ & $8 \mathrm{~m}$ & & & & \\
\hline & & & $18 \mathrm{mo}$ & $8<\mathrm{I}$ & $J<$ & & & & \\
\hline & & & 2 year & $\mathrm{DAI}$ & $3 \mathrm{yc}$ & & & & \\
\hline & & & 3 year & $\mathrm{DAI}$ & $4 \mathrm{yc}$ & & & & \\
\hline & & & 4 year & $\mathrm{DAI}$ & $5 \mathrm{yc}$ & & & & \\
\hline & & & DAV > & year & & & & & \\
\hline & $\begin{array}{l}\text { Diversity of } \\
\text { varieties and } \\
\text { animal breeds }\end{array}$ & $\begin{array}{l}\text { Number of on-farm plant } \\
\text { varieties (DV) and animal } \\
\text { breeds raised for production }\end{array}$ & $\begin{array}{l}\text { DVR = } \\
\text { Benchn } \\
\text { In the c } \\
\text { monoct } \\
\text { one-bre } \\
\text { Scoring }\end{array}$ & $\begin{array}{l}J+1 \\
\text { x: D } \\
\text { of I } \\
\text { re ( } 1 \\
\text { anin } \\
\text { ale: }\end{array}$ & $\begin{array}{l}\text { AA } \\
=2 \\
=1 \\
\text { o-v } \\
\text { hust }\end{array}$ & & & st & \\
\hline & (DVR) & (NRAA) & DRV & 1 & 2 & 3 & 4 & 5 & 6 \\
\hline & & & Score & 1 & 2 & 3 & 4 & 5 & 6 \\
\hline
\end{tabular}


Supplementary material 2 - Environmental indicators on land use and management.

\begin{tabular}{|c|c|c|c|}
\hline$\underset{\Xi}{\Xi}$ & Indicators & Description of indicators & $\begin{array}{l}\text { Calculation methods, thresholds } \\
\text { and scoring scales }\end{array}$ \\
\hline \multirow{4}{*}{ 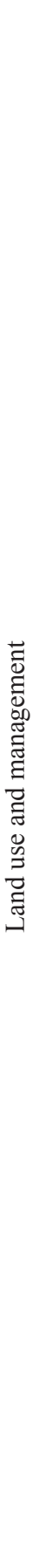 } & $\begin{array}{l}\text { Application } \\
\text { of soil } \\
\text { conservation } \\
\text { practices }\end{array}$ & $\begin{array}{l}\text { Quantitative indicator } \\
\text { to evaluate the on-farm } \\
\text { application of practices } \\
\text { directed towards the } \\
\text { conservation/improvement } \\
\text { of the chemico-physical and } \\
\text { biological properties of the } \\
\text { agricultural soil }\end{array}$ & $\begin{array}{l}\text { Share of farm's UAA on which soil conservation } \\
\text { practices are applied. The following are intended as } \\
\text { practices that allow conserving and/or improving } \\
\text { the chemical, physical and biological properties of } \\
\text { the agricultural soil: } \\
\text { - Application of organic fertilizers (e.g. compost, } \\
\text { manure...); } \\
\text { - Application of soil improvers (to improve soil } \\
\text { physical characteristics) and conditioners (to } \\
\text { improve soil chemical characteristics); } \\
\text { - Improving drainage to reduce water stagnation. } \\
\text { Scoring scale: } 0 \text { (no application) to } 10 \text { (application } \\
\text { on } 100 \% \text { of UAA). }\end{array}$ \\
\hline & $\begin{array}{l}\text { Soil erosion } \\
\text { protection }\end{array}$ & $\begin{array}{l}\text { Quantitative indicator } \\
\text { to evaluate the on-farm } \\
\text { application of practices to } \\
\text { reduce the risk of wind and } \\
\text { water erosion }\end{array}$ & $\begin{array}{l}\text { Share of farm's UAA on which practices for soil } \\
\text { protection against water and wind erosion are } \\
\text { applied. The following are considered as practices } \\
\text { of soil protection against erosion: crop rotation } \\
\text { (including cover crops, fallow, forages), hedges } \\
\text { as windbreaks, mulching and grassing, agro- } \\
\text { forestation, terracing, strip cropping, protective } \\
\text { grassy strips, drainage channels. } \\
\text { Scoring scale: } 0 \text { (no application) to } 10 \text { (application } \\
\text { on } 100 \% \text { of UAA). }\end{array}$ \\
\hline & $\begin{array}{l}\text { Input of } \\
\text { nitrogen } \\
\text { fertilisers }\end{array}$ & $\begin{array}{l}\text { It provides an estimate of } \\
\text { the rate of application of } \\
\text { nitrogen-based products in } \\
\text { the fertilisable UAA (UAA } \\
\text { usually fertilised) }\end{array}$ & $\begin{array}{l}\text { This indicator considers the total amount of mineral } \\
\text { fertilizers distributed on the farm (ammonium } \\
\text { sulphate, calcium cyanamide, ammonium and } \\
\text { calcium nitrate, agricultural urea) in quintals. This } \\
\text { amount is compared to the treated area (i.e. UAA - } \\
\text { permanent meadows and pastures) in ha. } \\
\text { Scoring scale: The consumption classes can be } \\
\text { aggregated as follows: } \\
\text { - High: }>1.5 \text { (score: } 0-3 \text { ); } \\
\text { - Medium: } 1-1.5 \text { (score: } 4-6 \text { ); } \\
\text { - Low: }<1 \text { (score: } 7-10) \text {. }\end{array}$ \\
\hline & $\begin{array}{l}\text { Input of plant } \\
\text { protection } \\
\text { products }\end{array}$ & $\begin{array}{l}\text { It provides an estimate of the } \\
\text { rate of application of plant } \\
\text { protection products in the } \\
\text { treatable UAA }\end{array}$ & $\begin{array}{l}\text { The indicator considers the total amount of } \\
\text { plant protection products distributed on the } \\
\text { farm, expressed in kg per year, regardless of } \\
\text { toxicity classes. The amount is compared to the } \\
\text { treated area (i.e. UAA - permanent meadows and } \\
\text { pastures) in ha. } \\
\text { Scoring scale: The classes of plant protection } \\
\text { products use can be aggregated as follows: } \\
\text { - High: }>10 \mathrm{~kg} / \text { year (score: } 0-3 \text { ); } \\
\text { - Medium: } 5-10 \mathrm{~kg} / \text { year (score: } 4-6 \text { ); } \\
\text { - Low: }<5 \mathrm{~kg} / \text { year (score: } 7-10 \text { ). }\end{array}$ \\
\hline
\end{tabular}




\begin{tabular}{|c|c|c|c|}
\hline 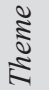 & Indicators & Description of indicators & $\begin{array}{c}\text { Calculation methods, thresholds } \\
\text { and scoring scales }\end{array}$ \\
\hline 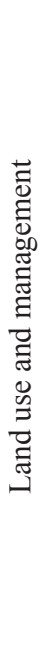 & $\begin{array}{l}\text { Use of } \\
\text { agricultural } \\
\text { machinery }\end{array}$ & $\begin{array}{l}\text { It provides an estimate } \\
\text { of agricultural machines } \\
\text { trafficking intensity in the } \\
\text { normally mechanized UAA } \\
\text { for cultural operations } \\
\text { (planting, preparatory and } \\
\text { field works, weed control and } \\
\text { plant protection treatments, } \\
\text { harvest operations) and an } \\
\text { indirect assessment of the } \\
\text { deteriorating action caused to } \\
\text { the soil physical properties }\end{array}$ & $\begin{array}{l}\text { The composition of the machinery park, including } \\
\text { machines number and average power, is determined } \\
\text { from the firm survey. From these data, the } \\
\text { number and average power in } \mathrm{kW} \text { of tractors and } \\
\text { combine harvesters are extracted. These values are } \\
\text { multiplied by the average weight per } \mathrm{kW} \text { of power } \\
\text { of the machines (set indicatively at } 0.50 \mathrm{q} / \mathrm{kW} \text { ) and } \\
\text { by the number of passes in the field (ploughing, } \\
\text { seedbed preparation, fertilization, weeding, } \\
\text { phytosanitary treatments, for an indicative total of } \\
\text { 5). The obtained value is compared to the treatable } \\
\text { area (arable land, forage crops, trees) in ha. } \\
\text { Scoring scale: The classes of machinery use can be } \\
\text { aggregated as follows: } \\
\text { - High: }>5.0 \text { (score: } 0-3 \text { ); } \\
\text { - Medium: } 2.5 \text { to } 5.0 \text { (score: } 4-6 \text { ); } \\
\text { - Low: }<2.5 \text { (score: } 7-10 \text { ). }\end{array}$ \\
\hline
\end{tabular}


Supplementary material 3 - Environmental indicators: Energy use and climate change theme.

\begin{tabular}{|c|c|c|c|c|}
\hline$\stackrel{\Xi}{\Xi}$ & Indicators & $\begin{array}{l}\text { Description } \\
\text { of indicators }\end{array}$ & \multicolumn{2}{|l|}{$\begin{array}{l}\text { Calculation methods, benchmarks } \\
\text { and scoring scales }\end{array}$} \\
\hline \multirow{12}{*}{ 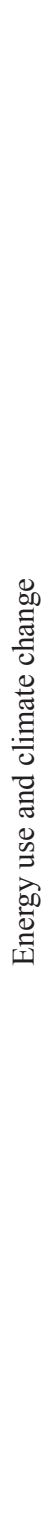 } & \multirow[t]{12}{*}{$\begin{array}{l}\text { Final Energy } \\
\text { Consumption } \\
(\text { FEC) }\end{array}$} & \multirow{12}{*}{$\begin{array}{l}\text { This indicator } \\
\text { monitors the use } \\
\text { of direct energy } \\
\text { at the farm level } \\
\text { and measures } \\
\text { the energy spent } \\
\text { for cultural } \\
\text { operations, } \\
\text { heating, irrigation } \\
\text { and different } \\
\text { agricultural } \\
\text { activities (drying, } \\
\text { milling, pressing, } \\
\text { cheese-making, } \\
\text { slaughtering, etc.) }\end{array}$} & \multicolumn{2}{|c|}{$\begin{array}{l}\text { The indicator is calculated based on the consumption of: } \\
\text { a) Petroleum fuels: purchase of fuels (gasoline, oil, diesel, LPG, } \\
\text { etc.), used for agricultural machinery and equipment. } \\
\text { b) Electricity consumed for agricultural activity, excluding the } \\
\text { energy consumed by the holder's family. } \\
\text { c) Fuels: solid fuels (wood, peat, coal, etc.), liquid fuels (fuel } \\
\text { oil, gasoline, diesel oil, etc.) and gaseous fuels (methane, etc.) } \\
\text { not used for firm vehicles, machinery and equipment, but for } \\
\text { heating, refrigeration, corporate lighting, etc. } \\
\text { The whole energy consumption is related to the farm area } \\
\text { (UAA). } \\
\text { The energy contained in electricity and fuel is expressed in MJ / } \\
\text { kg or MJ / ( using LHV of fuels). } \\
\text { Benchmark (FEC B) = 8.73 GJ/ha UAA } \\
\text { The benchmark is calculated as the average value of the } \\
\text { indicator for the agricultural sector in Apulia based on data from } \\
\text { ENEA, ISTAT and the information system of Apulia region } \\
\text { (Bellini, Lipizzi, Consentino, \& Giordano, 2013; ENEA-UTEE, } \\
\text { 2011). } \\
\text { Scoring scale: }\end{array}$} \\
\hline & & & FEC & Score \\
\hline & & & $\mathrm{FEC}>200 \% \mathrm{FEC}_{\mathrm{B}}$ & 1 \\
\hline & & & $\mathrm{FEC} \in\left[175 \% * \mathrm{FEC}_{\mathrm{B}}, 200 \% * \mathrm{FEC}_{\mathrm{B}}\right]$ & 2 \\
\hline & & & $\mathrm{FEC} \in\left[150 \% * \mathrm{FEC}_{\mathrm{B}}, 175 \% * \mathrm{FEC}_{\mathrm{B}}\right]$ & 3 \\
\hline & & & $\mathrm{FEC} \in\left[125 \% * \mathrm{FEC}_{\mathrm{B}}, 50 \% * \mathrm{FEC}_{\mathrm{B}}\right]$ & 4 \\
\hline & & & $\mathrm{FEC} \in\left[+25 \% * \mathrm{FEC}_{\mathrm{B}},-25 \% * \mathrm{FEC}_{\mathrm{B}}\right]$ & 5 (benchmark) \\
\hline & & & $\mathrm{FEC} \in\left[50 \% * \mathrm{FEC}_{\mathrm{B}}, 75 \% * \mathrm{FEC}_{\mathrm{B}}\right]$ & 6 \\
\hline & & & $\mathrm{FEC} \in\left[25 \% * \mathrm{FEC}_{\mathrm{B}}, 50 \% * \mathrm{FEC}_{\mathrm{B}}\right]$ & 7 \\
\hline & & & $\begin{array}{l}\mathrm{FEC} \in\left[0,25 \% * \mathrm{FEC}_{\mathrm{B}}\right] \text { or the firm uses only } \\
\text { biomass as combustible energy source that is } \\
\text { purchased from third parties for at least } 80 \%\end{array}$ & 8 \\
\hline & & & $\begin{array}{l}\mathrm{FEC}=0 \text { (the only source of combustible } \\
\text { energy used by the firm is bioenergy with a } \\
\text { maximum quota purchased from third parties } \\
\text { of } 20 \% \text { ). }\end{array}$ & 9 \\
\hline & & & FEC $=0$ (no combustible energy source) & 10 \\
\hline
\end{tabular}




\begin{tabular}{|c|c|c|c|c|}
\hline हี & Indicators & $\begin{array}{l}\text { Description } \\
\text { of indicators }\end{array}$ & \multicolumn{2}{|l|}{$\begin{array}{l}\text { Calculation methods, benchmarks } \\
\text { and scoring scales }\end{array}$} \\
\hline \multirow{12}{*}{ 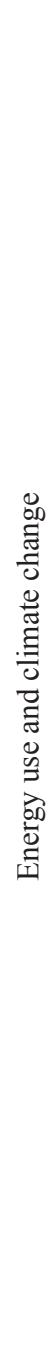 } & \multirow{12}{*}{$\begin{array}{l}\text { Mineral } \\
\text { Fertilizers } \\
\text { Consumption } \\
\text { (MFC) }\end{array}$} & \multirow{12}{*}{$\begin{array}{l}\text { This indicator } \\
\text { assesses the } \\
\text { consumption of } \\
\text { the primary energy } \\
\text { contained in } \\
\text { mineral fertilisers } \\
\text { used in the farm }\end{array}$} & \multicolumn{2}{|c|}{$\begin{array}{l}\text { The indicator is calculated by converting (through coefficients) } \\
\text { the quantities of mineral fertilizers, expressed as kg of } \mathrm{N} \text { and } \mathrm{P} \\
\text { (P2O5), into energy. } \\
\text { Fertilizer quantities are converted into MJ / ha UAA as follows } \\
\text { (Eurostat, 2015): } \\
\text { - } 58.17 \mathrm{MJ} \text { per kg N } \\
\text { - } 14.16 \mathrm{MJ} \text { per kg P } \\
\text { The average consumption of nitrogen and phosphate fertilizers, } \\
\text { calculated from the ISTAT data for Apulia region for } 2012 \\
\text { (ISTAT, } 2014,2019 \text { a) are: } \\
\text { - } 42 \mathrm{~kg} \mathrm{~N} / \text { ha UAA } \\
\text { - } 12 \mathrm{~kg} \text { P2O5 / ha UAA } \\
\text { In energy terms, the benchmarks are: } \\
\text { - MFC-N: } 2.44 \text { GJ N / ha UAA } \\
\text { - MFC-P: } 0.171 \mathrm{GJ} \text { P2O5 / ha UAA } \\
\text { - MFC }=2.92 \mathrm{GJ} / \text { ha UAA } \\
\text { Scoring scale: }\end{array}$} \\
\hline & & & MFC & Score \\
\hline & & & MFC $>200 \% \mathrm{MFC}_{\mathrm{B}}$ & 1 \\
\hline & & & $\mathrm{MFC} \in\left[175 \% * \mathrm{MFC}_{\mathrm{B}}, 200 \% * \mathrm{MFC}_{\mathrm{B}}\right]$ & 2 \\
\hline & & & $\mathrm{MFC} \in\left[150 \% * \mathrm{MFC}_{\mathrm{B}}, 175 \% * \mathrm{MFC}_{\mathrm{B}}\right]$ & 3 \\
\hline & & & $\mathrm{MFC} \in\left[125 \% * \mathrm{MFC}_{\mathrm{B}}, 150 \% * \mathrm{MFC}_{\mathrm{B}}\right]$ & 4 \\
\hline & & & $\mathrm{MFC} \in\left[+25 \% * \mathrm{MFC}_{\mathrm{B}},-25 \% * \mathrm{MFC}_{\mathrm{B}}\right]$ & 5 (benchmark) \\
\hline & & & MFC $\in\left[50 \% * \mathrm{MFC}_{\mathrm{B}}, 75 \% * \mathrm{MFC}_{\mathrm{B}}\right)$ & 6 \\
\hline & & & $\mathrm{MFC} \in\left[25 \% * \mathrm{MFC}_{\mathrm{B}}, 50 \% * \mathrm{MFC}_{\mathrm{B}}\right)$ & 7 \\
\hline & & & $\mathrm{MFC} \in\left[0,25 \% * \mathrm{MFC}_{\mathrm{B}}\right]$ & 8 \\
\hline & & & $\begin{array}{l}\text { MFC }=0 \text { (exclusive consumption of organic } \\
\text { fertilizers, purchased from third parties for at } \\
\text { least } 80 \% \text { ) }\end{array}$ & 9 \\
\hline & & & $\begin{array}{l}\text { MFC }=0 \text { (exclusive consumption of organic } \\
\text { fertilizers, self-produced in the firm for at } \\
\text { least } 80 \% \text { ) }\end{array}$ & 10 \\
\hline
\end{tabular}




\begin{tabular}{|c|c|c|c|c|}
\hline हี & Indicators & $\begin{array}{l}\text { Description } \\
\text { of indicators }\end{array}$ & \multicolumn{2}{|c|}{$\begin{array}{l}\text { Calculation methods, benchmarks } \\
\text { and scoring scales }\end{array}$} \\
\hline \multirow{12}{*}{ 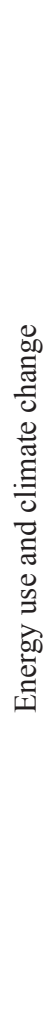 } & \multirow[t]{12}{*}{$\begin{array}{l}\text { Pesticide } \\
\text { Consumption } \\
\text { (PC) }\end{array}$} & \multirow{12}{*}{$\begin{array}{l}\text { This indicator } \\
\text { is aimed to } \\
\text { monitor the } \\
\text { consumption of } \\
\text { fuel energy used } \\
\text { to produce the } \\
\text { plant protection } \\
\text { products or fossil } \\
\text { energy sources } \\
\text { belonging to } \\
\text { the primary } \\
\text { feedstock of the } \\
\text { plant protection } \\
\text { products used in } \\
\text { the farm }\end{array}$} & \multicolumn{2}{|c|}{$\begin{array}{l}\text { The indicator is calculated by converting (through coefficients) } \\
\text { the quantities of pesticides (expressed in kg) into energy. } \\
\text { The quantities of pesticides are converted into MJ / ha UAA } \\
\text { as follows (Ecoinvent, 2014): } 182.91 \mathrm{MJ} \text { per kg of generic } \\
\text { pesticide available on the market. } \\
\text { The benchmark }\left(\mathrm{PC}_{\mathrm{B}} \text { ) is } 1.80 \mathrm{GJ} / \text { ha UAA and was calculated }\right. \\
\text { using the average quantity of pesticides per ha of UAA } \\
\text { distributed in } 2012 \text { in Apulia i.e. } 9.88 \mathrm{~kg} / \text { ha UAA (ISTAT, } \\
2019 \mathrm{~b} \text { ) multiplying it by the average energy content estimated } \\
\text { by the Ecoinvent database (Ecoinvent, 2014). } \\
\text { Scoring scale: }\end{array}$} \\
\hline & & & $\mathrm{PC}$ & Score \\
\hline & & & $\mathrm{PC}>200 \% \mathrm{PC}_{\mathrm{B}}$ & 1 \\
\hline & & & $\mathrm{PC} \in\left[175 \% * \mathrm{PC}_{\mathrm{B}}, 200 \% * \mathrm{PC}_{\mathrm{B}}\right]$ & 2 \\
\hline & & & $\mathrm{PC} \in\left[150 \% * \mathrm{PC}_{\mathrm{B}}, 175 \% * \mathrm{PC}_{\mathrm{B}}\right]$ & 3 \\
\hline & & & $\mathrm{PC} \in\left[125 \% * \mathrm{PC}_{\mathrm{B}}, 150 \% * \mathrm{PC}_{\mathrm{B}}\right]$ & 4 \\
\hline & & & $\mathrm{PC} \in\left[+25 \% * \mathrm{PC}_{\mathrm{B}},-25 \% * \mathrm{PC}_{\mathrm{B}}\right]$ & 5 (benchmark) \\
\hline & & & $\mathrm{PC} \in\left[50 \% * \mathrm{PC}_{\mathrm{B}}, 75 \% * \mathrm{PC}_{\mathrm{B}}\right]$ & 6 \\
\hline & & & $\mathrm{PC} \in\left[25 \% * \mathrm{PC}_{\mathrm{B}}, 50 \% * \mathrm{PC}^{\mathrm{B}}\right]$ & 7 \\
\hline & & & $\mathrm{PC} \in\left[0,25 \% * \mathrm{PC}_{\mathrm{B}}\right]$ & 8 \\
\hline & & & $\mathrm{PC}=0$ (no use of pesticides on crops) & 9 \\
\hline & & & $\begin{array}{l}\mathrm{PC}=0 \text { (no use of pesticides, including non- } \\
\text { curative uses on livestock) }\end{array}$ & 10 \\
\hline
\end{tabular}




\begin{tabular}{|c|c|c|c|c|}
\hline$\underset{\Xi}{\Xi}$ & Indicators & $\begin{array}{l}\text { Description } \\
\text { of indicators }\end{array}$ & \multicolumn{2}{|c|}{$\begin{array}{l}\text { Calculation methods, benchmarks } \\
\text { and scoring scales }\end{array}$} \\
\hline \multirow{11}{*}{ 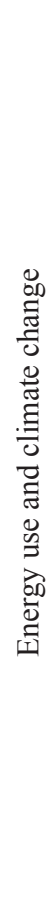 } & \multirow[t]{11}{*}{$\begin{array}{l}\text { Lubricant } \\
\text { Consumption } \\
\text { (LC) }\end{array}$} & \multirow{11}{*}{$\begin{array}{l}\text { This indicator } \\
\text { monitors the } \\
\text { consumption of } \\
\text { the fuel energy } \\
\text { used to produce } \\
\text { lubricants for } \\
\text { agricultural } \\
\text { machines (tractors } \\
\text { and machinery) }\end{array}$} & \multicolumn{2}{|c|}{$\begin{array}{l}\text { The indicator is calculated by converting (through coefficients) } \\
\text { the quantities of lubricants (expressed in } \mathrm{kg} \text { ) into energy. } \\
\text { The quantities of lubricants are converted into } \mathrm{MJ} / \text { ha UAA as } \\
\text { follows (Ecoinvent, 2014): } 81.73 \mathrm{MJ} \text { per kg of generic lubricant } \\
\text { available on the market. } \\
\text { Due to lack of ISTAT data, the benchmark value }\left(\mathrm{LC}_{\mathrm{B}}\right) \text { will } \\
\text { be calculated using the average amount of lubricants per } \\
\text { hectare used by Apulian companies requesting environmental } \\
\text { certification. } \\
\text { Scoring scale: }\end{array}$} \\
\hline & & & LC & Score \\
\hline & & & $\mathrm{LC}>200 \% \mathrm{LC}_{\mathrm{B}}$ & 1 \\
\hline & & & $\mathrm{LC} \in\left[175 \% * \mathrm{LC}_{\mathrm{B}}, 200 \% * \mathrm{LC}_{\mathrm{B}}\right]$ & 2 \\
\hline & & & $\mathrm{LC} \in\left[150 \% * \mathrm{LC}_{\mathrm{B}}, 175 \% * \mathrm{LC}_{\mathrm{B}}\right]$ & 3 \\
\hline & & & $\mathrm{LC} \in\left[125 \% * \mathrm{LC}_{\mathrm{B}}, 150 \% * \mathrm{LC}_{\mathrm{B}}\right]$ & 4 \\
\hline & & & $\mathrm{LC} \in\left[+25 \% * \mathrm{LC}_{\mathrm{B}},-25 \% * \mathrm{LC}_{\mathrm{B}}\right]$ & 5 (benchmark) \\
\hline & & & $\mathrm{LC} \in\left[50 \% * \mathrm{LC}_{\mathrm{B}}, 75 \% * \mathrm{LC}_{\mathrm{B}}\right]$ & 6 \\
\hline & & & $\mathrm{LC} \in\left[25 \% * \mathrm{LC}_{\mathrm{B}}, 50 \% * \mathrm{LC}_{\mathrm{B}}\right]$ & 7 \\
\hline & & & $\mathrm{LC} \in\left(0,25 \% * \mathrm{LC}_{\mathrm{B}}\right]$ & 8 \\
\hline & & & $\mathrm{LC}=0$ & 10 \\
\hline
\end{tabular}




\begin{tabular}{|c|c|c|c|c|}
\hline हี & Indicators & $\begin{array}{l}\text { Description } \\
\text { of indicators }\end{array}$ & \multicolumn{2}{|c|}{$\begin{array}{l}\text { Calculation methods, benchmarks } \\
\text { and scoring scales }\end{array}$} \\
\hline \multirow{12}{*}{ 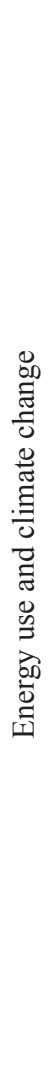 } & \multirow{12}{*}{$\begin{array}{l}\text { Plastic } \\
\text { Material } \\
\text { Consumption } \\
\text { (PMC) }\end{array}$} & \multirow{12}{*}{$\begin{array}{l}\text { This indicator is } \\
\text { aimed to monitor } \\
\text { the consumption } \\
\text { of the energy used } \\
\text { to produce the } \\
\text { plastic materials } \\
\text { used in the farm }\end{array}$} & \multicolumn{2}{|c|}{$\begin{array}{l}\text { The indicator is calculated through the conversion (via } \\
\text { coefficients) of the quantities of plastic materials (expressed in } \\
\mathrm{kg} \text { ) into energy. } \\
\text { The quantities of plastic materials are converted into MJ / ha } \\
\text { UAA as follows (Audsley, 1997): } 94.02 \mathrm{MJ} \text { per kg of plastic } \\
\text { material (using the value corresponding to the most common } \\
\text { plastic materials e.g. polyethylene). Bio-plastics are excluded } \\
\text { from the count. } \\
\text { Due to the lack of ISTAT data, the benchmark (PMC } \mathrm{B}_{\mathrm{B}} \text { ) will be } \\
\text { calculated using the average quantity of plastic materials per } \\
\text { UAA used by Apulian companies that request environmental } \\
\text { certification. } \\
\text { Scoring scale: }\end{array}$} \\
\hline & & & PMC & Score \\
\hline & & & $\mathrm{PMC}>200 \% \mathrm{PMC}_{\mathrm{B}}$ & 1 \\
\hline & & & $\mathrm{PMC} \in\left[175 \% * \mathrm{PMC}_{\mathrm{B}}, 200 \% * \mathrm{PMC}_{\mathrm{B}}\right]$ & 2 \\
\hline & & & $\mathrm{PMC} \in\left[150 \% * \mathrm{PMC}_{\mathrm{B}}, 175 \% * \mathrm{PMC}_{\mathrm{B}}\right]$ & 3 \\
\hline & & & $\mathrm{PMC} \in\left[125 \% * \mathrm{PMC}_{\mathrm{B}}, 150 \% * \mathrm{PMC}_{\mathrm{B}}\right]$ & 4 \\
\hline & & & $\mathrm{PMC} \in\left[+25 \% * \mathrm{PMC}_{\mathrm{B}},-25 \% * \mathrm{PMC}_{\mathrm{B}}\right]$ & 5 (benchmark) \\
\hline & & & $\mathrm{PMC} \in\left[50 \% * \mathrm{PMC}_{\mathrm{B}}, 75 \% * \mathrm{PMC}_{\mathrm{B}}\right]$ & 6 \\
\hline & & & $\mathrm{PMC} \in\left[25 \% * \mathrm{PMC}_{\mathrm{B}}, 50 \% * \mathrm{PMC}_{\mathrm{B}}\right]$ & 7 \\
\hline & & & $\mathrm{PMC} \in\left(0,25 \% * \mathrm{PMC}_{\mathrm{B}}\right]$ & 8 \\
\hline & & & PMC = 0 (only use of bio-plastics) & 9 \\
\hline & & & PMC $=0$ (no use of plastics) & 10 \\
\hline
\end{tabular}




\begin{tabular}{|c|c|c|c|c|}
\hline$\underset{\Xi}{\Xi}$ & Indicators & $\begin{array}{l}\text { Description } \\
\text { of indicators }\end{array}$ & \multicolumn{2}{|c|}{$\begin{array}{l}\text { Calculation methods, benchmarks } \\
\text { and scoring scales }\end{array}$} \\
\hline \multirow{11}{*}{ 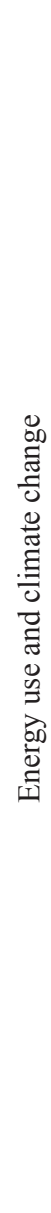 } & \multirow[t]{11}{*}{$\begin{array}{l}\text { Use of off- } \\
\text { farm animal } \\
\text { feeds (FC) }\end{array}$} & \multirow{11}{*}{$\begin{array}{l}\text { This indicator } \\
\text { aims to monitor } \\
\text { the consumption } \\
\text { of the fuel energy } \\
\text { used to produce } \\
\text { the animal feeds } \\
\text { that are not } \\
\text { produced within } \\
\text { the farm, but are } \\
\text { purchased }\end{array}$} & \multicolumn{2}{|c|}{$\begin{array}{l}\text { The indicator is calculated by converting (through coefficients) } \\
\text { the quantities of non-self-produced feed used by the firm } \\
\text { (expressed in kg) into energy. } \\
\text { The LCA databases do not contain average values for the } \\
\text { feed used, given the extreme variability of these, the different } \\
\text { production methods (e.g. organic, conventional, integrated } \\
\text { production) and geographical environments. It is therefore } \\
\text { necessary to determine the coefficients according to the type of } \\
\text { feed used by the firm and to try to approximate it with existing } \\
\text { data. These data are available for the Netherlands and for } \\
\text { Switzerland in the LCA databases e.g. Agrifootprint database } \\
\text { (Ecoinvent, 2014). } \\
\text { The benchmark (FCB) is calculated using the average mix of } \\
\text { feed used in Apulia region for the reference year (currently } \\
\text { 2012) and its average quantity used by companies that request } \\
\text { environmental certification. } \\
\text { Scoring scale: }\end{array}$} \\
\hline & & & FC & Score \\
\hline & & & $\mathrm{FC}>200 \% \mathrm{FC}_{\mathrm{B}}$ & 1 \\
\hline & & & $\mathrm{FC} \in\left[175 \% * \mathrm{FC}_{\mathrm{B}}, 200 \% * \mathrm{FC}_{\mathrm{B}}\right]$ & 2 \\
\hline & & & $\mathrm{FC} \in\left[150 \% * \mathrm{FC}_{\mathrm{B}}, 175 \% * \mathrm{FC}_{\mathrm{B}}\right]$ & 3 \\
\hline & & & $\mathrm{FC} \in\left[125 \% * \mathrm{FC}_{\mathrm{B}}, 150 \% * \mathrm{FC}_{\mathrm{B}}\right]$ & 4 \\
\hline & & & $\mathrm{FC} \in\left[+25 \% * \mathrm{FC}_{\mathrm{B}},-25 \% * \mathrm{FC}_{\mathrm{B}}\right]$ & 5 (benchmark) \\
\hline & & & $\mathrm{FC} \in\left[50 \% * \mathrm{FC}_{\mathrm{B}}, 75 \% * \mathrm{FC}_{\mathrm{B}}\right)$ & 6 \\
\hline & & & $\mathrm{FC} \in\left[25 \% * \mathrm{FC}_{\mathrm{B}}, 50 \% * \mathrm{FC}_{\mathrm{B}}\right)$ & 7 \\
\hline & & & $\mathrm{FC} \in\left[0,25 \% * \mathrm{FC}_{\mathrm{B}}\right]$ & 8 \\
\hline & & & \begin{tabular}{|l}
$\mathrm{FC}=0$ (exclusive consumption of self- \\
produced feed)
\end{tabular} & 10 \\
\hline
\end{tabular}


Supplementary material 4. Environmental indicators relating to the use of chemical inputs theme.

\begin{tabular}{|c|c|c|c|c|}
\hline$\underset{\Xi}{\Xi}$ & Indicators & Description of indicators & \multicolumn{2}{|c|}{$\begin{array}{l}\text { Calculation methods, thresholds/benchmarks } \\
\text { and scoring scales }\end{array}$} \\
\hline \multirow{26}{*}{ 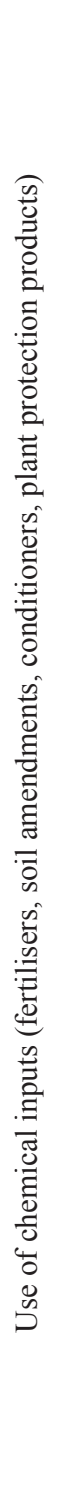 } & \multirow{13}{*}{$\begin{array}{l}\text { Nitrogen } \\
\text { consumption } \\
\left(\mathrm{N}_{\text {tot }}\right)\end{array}$} & \multirow{13}{*}{$\begin{array}{l}\text { This indicator is aimed to } \\
\text { assess the } \mathrm{N} \text { inputs applied } \\
\text { at the farm level as related to } \\
\text { the regional mean }\end{array}$} & \multicolumn{2}{|c|}{$\begin{array}{l}\text { Benchmark: } 42 \mathrm{~kg} \mathrm{ha}^{-1} \text { i.e. average use of } \mathrm{N} \text { in } \\
\text { Apulia region calculated from ISTAT data referring } \\
\text { to } 2012 \text { (ISTAT, 2019a); The value corresponding } \\
\text { to the minimum score is that recommended by the } \\
\text { Nitrates Directive }\left(170 \mathrm{~kg} \mathrm{ha}^{-1}\right) \text { for areas at risk. } \\
\text { Scoring scale: }\end{array}$} \\
\hline & & & $\mathrm{N}_{\text {tot }}\left(\mathrm{kg} \mathrm{ha}^{-1}\right)$ & Score \\
\hline & & & $\begin{array}{l}\text { Nitrogen fertilization without } \\
\text { soil analysis }\end{array}$ & 1 \\
\hline & & & $170>N_{\text {tot }}>84$ & 1 \\
\hline & & & $84>\mathrm{N}_{\text {tot }}>73.5$ & 2 \\
\hline & & & $73.5>\mathrm{N}_{\text {tot }}>63$ & 3 \\
\hline & & & $63>\mathrm{N}_{\text {tot }}>52.5$ & 4 \\
\hline & & & $52.5>\mathrm{N}_{\text {tot }}>42$ & 5 \\
\hline & & & $42>\mathrm{N}_{\text {tot }}>31.5$ & 6 \\
\hline & & & $31.5>\mathrm{N}_{\text {tot }}>21$ & 7 \\
\hline & & & $21>\mathrm{N}_{\text {tot }}>10.5$ & 8 \\
\hline & & & $10.5>\mathrm{N}_{\mathrm{tot}}>0$ & 9 \\
\hline & & & Ntot $=0$ & 10 \\
\hline & \multirow{13}{*}{$\begin{array}{l}\text { Use of total } \\
\text { phosphorus } \\
\text { pentoxide } \\
\left(\mathrm{P}_{2} \mathrm{O}_{5}\right)\left(\mathrm{P}_{\mathrm{tot}}\right)\end{array}$} & \multirow{13}{*}{$\begin{array}{l}\text { It assesses phosphorus inputs } \\
\text { at the farm level as related to } \\
\text { the regional average }\end{array}$} & \multicolumn{2}{|c|}{$\begin{array}{l}\text { Benchmark: } 12 \mathrm{~kg} \mathrm{ha}^{-1} \text { i.e. average input of total } \mathrm{P} \text {, } \\
\text { expressed as phosphorus pentoxide, calculated from } \\
\text { ISTAT data referring to } 2012 \text { (ISTAT, 2019a). } \\
\text { Scoring scale: }\end{array}$} \\
\hline & & & $\mathrm{P}\left(\mathrm{kg} \mathrm{ha}^{-1}\right)$ & Score \\
\hline & & & $\begin{array}{l}\text { Phosphate fertilization without } \\
\text { soil analysis }\end{array}$ & 1 \\
\hline & & & $\mathrm{P}>24$ & 1 \\
\hline & & & $24>P>21$ & 2 \\
\hline & & & $21>\mathrm{P}>18$ & 3 \\
\hline & & & $18>\mathrm{P}>15$ & 4 \\
\hline & & & $15>P>12$ & 5 \\
\hline & & & $12>\mathrm{P}>9$ & 6 \\
\hline & & & $9>P>6$ & 7 \\
\hline & & & $6>P>3$ & 8 \\
\hline & & & $3>P>0$ & 9 \\
\hline & & & $\mathrm{P}=0$ & 10 \\
\hline
\end{tabular}




\begin{tabular}{|c|c|c|c|c|}
\hline 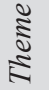 & Indicators & Description of indicators & \multicolumn{2}{|c|}{$\begin{array}{l}\text { Calculation methods, thresholds/benchmarks } \\
\text { and scoring scales }\end{array}$} \\
\hline \multirow{26}{*}{ 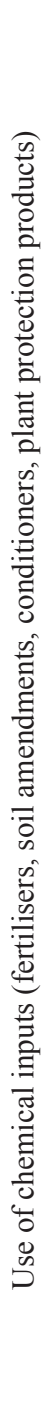 } & \multirow{13}{*}{$\begin{array}{l}\text { Use of } \\
\text { fungicides } \\
\left(\mathrm{F}_{\text {tot }}\right)\end{array}$} & \multirow{13}{*}{$\begin{array}{l}\text { This indicator is aimed } \\
\text { to assess the inputs of } \\
\text { fungicides applied at the } \\
\text { farm level as related to the } \\
\text { regional mean }\end{array}$} & \multicolumn{2}{|c|}{$\begin{array}{l}\text { Benchmark: } 5.15 \mathrm{~kg} \mathrm{ha}^{-1} \text { based on the average use } \\
\text { of fungicides in Apulia region in } 2012 \text { (ISTAT, } \\
\text { 2019b). } \\
\text { Scoring scale: }\end{array}$} \\
\hline & & & $\mathrm{F}\left(\mathrm{kg} \mathrm{ha}^{-1}\right)$ & Score \\
\hline & & & $\begin{array}{l}\text { Calendar-based treatments } \\
\text { without monitoring }\end{array}$ & 1 \\
\hline & & & $\mathrm{F}>10.3$ & 1 \\
\hline & & & $10.3>\mathrm{F}>9.013$ & 2 \\
\hline & & & $9.013>\mathrm{F}>7.725$ & 3 \\
\hline & & & $7.725>\mathrm{F}>6.438$ & 4 \\
\hline & & & $6.438>\mathrm{F}>5.15$ & 5 \\
\hline & & & $5.15>F>3.863$ & 6 \\
\hline & & & $3.863>\mathrm{F}>2.575$ & 7 \\
\hline & & & $2.575>\mathrm{F}>1.288$ & 8 \\
\hline & & & $1.288>\mathrm{F}>0$ & 9 \\
\hline & & & $\mathrm{F}=0$ & 10 \\
\hline & \multirow{13}{*}{$\begin{array}{l}\text { Use of } \\
\text { insecticides } \\
\text { and acaricides } \\
\text { (Ins } \text { tot }_{\text {) }}\end{array}$} & \multirow{13}{*}{$\begin{array}{l}\text { This indicator assesses the } \\
\text { inputs of insecticides and } \\
\text { acaricides applied at the } \\
\text { farm level as related to the } \\
\text { regional average }\end{array}$} & \multicolumn{2}{|c|}{$\begin{array}{l}\text { Benchmark: } 1.69 \mathrm{~kg} \mathrm{ha}^{-1} \text { i.e. average use of } \\
\text { insecticides and acaricides in Apulia region in } 2012 \\
\text { (ISTAT, 2019b). } \\
\text { Scoring scale: }\end{array}$} \\
\hline & & & Ins (kg ha-1) & Score \\
\hline & & & $\begin{array}{l}\text { Calendar-based treatments } \\
\text { without monitoring }\end{array}$ & 1 \\
\hline & & & Ins > 3.38 & 1 \\
\hline & & & $3.38>$ Ins $>2.958$ & 2 \\
\hline & & & $2.958>$ Ins $>2.535$ & 3 \\
\hline & & & $2.535>$ Ins $>2.113$ & 4 \\
\hline & & & $2.113>$ Ins $>1.69$ & 5 \\
\hline & & & $1.69>$ Ins $>1.268$ & 6 \\
\hline & & & $1.268>$ Ins $>0.845$ & 7 \\
\hline & & & $0.845>$ Ins $>0.423$ & 8 \\
\hline & & & $0.423>$ Ins $>0$ & 9 \\
\hline & & & Ins $=0$ & 10 \\
\hline
\end{tabular}




\begin{tabular}{|c|c|c|c|c|}
\hline हี & Indicators & Description of indicators & \multicolumn{2}{|c|}{$\begin{array}{c}\text { Calculation methods, thresholds/benchmarks } \\
\text { and scoring scales }\end{array}$} \\
\hline \multirow{13}{*}{ 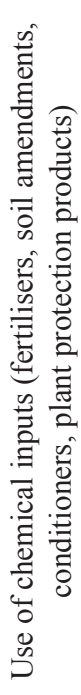 } & \multirow{13}{*}{$\begin{array}{l}\text { Use of } \\
\text { herbicides } \\
\left(\text { Herb }_{\text {tot }}\right)\end{array}$} & \multirow{13}{*}{$\begin{array}{l}\text { This indicator is aimed } \\
\text { to assess the inputs of } \\
\text { herbicides applied at the } \\
\text { farm level as related to the } \\
\text { regional mean }\end{array}$} & \multicolumn{2}{|c|}{$\begin{array}{l}\text { Benchmark: } 1.74 \mathrm{~kg} \mathrm{ha}^{-1} \text { corresponding to the } \\
\text { average use of herbicides in Apulia in } 2012 \text { (ISTAT, } \\
\text { 2019b). } \\
\text { Scoring scale: }\end{array}$} \\
\hline & & & $\operatorname{Herb}\left(\mathrm{kg} \mathrm{ha}^{-1}\right)$ & Score \\
\hline & & & $\begin{array}{l}\text { Calendar-based treatments } \\
\text { without monitoring }\end{array}$ & 1 \\
\hline & & & Herb $>3.48$ & 1 \\
\hline & & & $3.48>$ Herb $>3.05$ & 2 \\
\hline & & & $3.05>$ Herb $>2.61$ & 3 \\
\hline & & & $2.61>$ Herb $>2.18$ & 4 \\
\hline & & & $2.18>$ Herb $>1.74$ & 5 \\
\hline & & & $1.74>$ Herb $>1.31$ & 6 \\
\hline & & & $1.31>$ Herb $>0.78$ & 7 \\
\hline & & & $0.78>$ Herb $>0.44$ & 8 \\
\hline & & & $0.44>$ Herb $>0$ & 9 \\
\hline & & & Herb $=0$ & 10 \\
\hline
\end{tabular}


Supplementary material Table 5. Environmental indicators: waste management theme.

\begin{tabular}{|c|c|c|c|c|}
\hline$\frac{\sqrt{2}}{\tilde{2}}$ & Indicator & Description of indicator & \multicolumn{2}{|l|}{ Scoring scale } \\
\hline \multirow{8}{*}{ 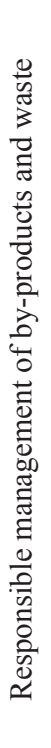 } & \multirow{8}{*}{$\begin{array}{l}\text { Methods } \\
\text { for the } \\
\text { management } \\
\text { of production } \\
\text { by-products } \\
\text { and waste }\end{array}$} & \multirow{8}{*}{$\begin{array}{l}\text { Qualitative indicator that } \\
\text { assesses the sustainability } \\
\text { of the management of } \\
\text { production by-products and } \\
\text { waste at the level of agri- } \\
\text { firms }\end{array}$} & \multicolumn{2}{|c|}{$\begin{array}{l}\text { In the scoring scale, different scores are assigned } \\
\text { to the different measures adopted by the agro-food } \\
\text { companies for the management of waste and by- } \\
\text { products. } \\
\text { The scores can be accumulated for each firm for a } \\
\text { maximum of } 10 \text { points. } \\
\text { Scoring scale: }\end{array}$} \\
\hline & & & Waste management method & Score \\
\hline & & & $\begin{array}{l}\text { Prevention and reduction (e.g. } \\
\text { concrete plans and strategies at the } \\
\text { firm level for the reduction of waste } \\
\text { production) }\end{array}$ & 6 \\
\hline & & & $\begin{array}{l}\text { Preparation for re-use (e.g. animal } \\
\text { feed) }\end{array}$ & 5 \\
\hline & & & Recycling (e.g. compost) & 5 \\
\hline & & & $\begin{array}{l}\text { Other types of recovery (e.g. energy } \\
\text { recovery) }\end{array}$ & 4 \\
\hline & & & Disposal under controlled conditions & 2 \\
\hline & & & Landfill / waste collection containers & 0 \\
\hline
\end{tabular}

\section{References}

Audsley E., 1997. Harmonisation of environmental life cycle assessment for agriculture. Final Report, Report Concerted Action AIR3-CT94-2028, EC DG VI Agriculture. Brussels. Retrieved from https:// www.researchgate.net/publication/258966401_ EU_Concerted_Action_report_HARMONISATION_OF_ENVIRONMENTAL_LIFE_CYCLE_ ASSESSMENT_FOR_AGRICULTURE_Final_ Report_Concerted_Action_AIR3-CT94-2028

Bellini G., Lipizzi F., Consentino F., Giordano P., 2013. $6^{\circ}$ Censimento Generale dell'Agricoltura Atlante dell'Agricoltura Italiana. Rome.

Ecoinvent, 2014. Ecoinvent database, v. 3.1. Retrieved March 23, 2015, from http://www.ecoinvent.org

ENEA-UTEE. 2011. Statistiche Energetiche Regionali, Puglia 1998-2008. Retrieved March 23,
2015, from http://www.efficienzaenergetica.enea. it/doc/2011/sier/15_Puglia.pdf

Eurostat, 2015. IRENA 08 - Mineral Fertiliser Consumption - IRENA Indicator Fact Sheet. Retrieved March 23, 2015, from https://circabc.europa.eu/ sd/a/7c3cc13f-7d2f-4d9a-b266-1371678e76de/ IRENA 08 - Mineral fertiliser consumption.pdf

ISTAT, 2014. VI Censimento generale dell'Agricoltura. Retrieved March 10, 2015, from https://censimentoagricoltura.istat.it

ISTAT, 2019a. Fertilizzanti. Retrieved May 15, 2019, from http://dati.istat.it/Index.aspx?DataSetCode=DCSP FERTILIZZANTI

ISTAT, 2019b. Fitosanitari. Retrieved from http:// dati.istat.it/Index.aspx? DataSetCode=DCSP FITOSANITARI 